Prof. dr. sc. Jozo Čizmić,

redoviti profesor u trajnom zvanju, Pravni fakultet Sveučilišta u Splitu

\title{
ZAŠTITA SPORTA PRAVIMA IZ PODRUČJA INTELEKTUALNOG VLASNIŠTVA
}

UDK: 796:347.77

DOI: 10.31141/zrpfs.2021.58.139.15

Izvorni znanstveni rad

Primljeno: 20. listopada 2020.

\begin{abstract}
Odnosi u sportu ne mogu se zamisliti izvan pravne uređenosti koju definira športsko pravo. Šport i pravna regulativa ogledaju se u dubokoj povezanosti, jer najznačajniji i najosnovniji element športa jest njegovo pravno uređenje i pravna zaštita. Autor je u radu prikazao pravno uređenje i zaštitu prava raznih subjekata u sportu pravima iz područja intelektualnog vlasništva.
\end{abstract}

Ključne riječi: sport, intelektualno vlasništvo

\section{UVOD}

Športom (ili sportom) nazivaju se fizičke aktivnosti koje čovjek izvodi iz raznih razloga. Riječ šport nekad je označavala svaku igru i zabavu. Danas se pod pojmom šport podrazumijevaju različite motoričke aktivnosti varijabilnog i dinamičkog karaktera u kojima na specifičan način dolaze do punog izražaja športaševe sposobnosti, osobine i znanja u treningu i natjecanju. U području športa egzistira nekoliko sustava i to su: profesionalni šport, amaterski šport, rekreacijski šport, školski šport i šport osoba s invaliditetom. Neki od razloga mogu biti razonoda, razvijanje tijela, poboljšanje sposobnosti, natjecateljski duh i tako dalje. ${ }^{1}$

Može se steći dojam da bavljenje sportskim aktivnostima donosi samo pozitivne učinke, ali u stvarnosti nastaju i problemi. Tamo gdje se radi o borbi za bodove i prvenstvo sport je postao toliko ozbiljna djelatnost da se ne može shvatiti ni u najširem smislu kao igra, iz koje je sport neosporno i potekao. ${ }^{2}$

Odnosi u sportu ne mogu se zamisliti izvan pravne uređenosti koju definira športsko pravo. Šport i pravna regulativa ogledaju se u dubokoj povezanosti, jer najznačajniji i najosnovniji element športa jest njegovo pravno uređenje. To se posebno odnosi na takmičarsku regulativu kao i na ostale prateće elemente organizacije športa. Osim toga, športske aktivnosti često se odvijaju izvan državnih granica, pri čemu dolazi do izražaja i njihova međunarodnopravna dimenzija.

1 Podatak na stranici: http://hr.wikipedia.org/wiki/\%C5\%A0port i https://hr.wikipedia.org/wiki/\%C 5\%A0port\#Uloga_\%C5\%A1porta_u_dru\%C5\%A1tvu; posjet 17. III. 2018.

2 Usp. ĐURĐEVIĆ, N., Javne vlasti u sportu, Kragujevac, 2007., str. 11. 
Sve to je utjecalo da se u području športa na nacionalnoj, a u novije vrijeme i na međunarodnoj razini, donose posebni pravni propisi iz kojih je proistekla specifična pravna praksa na području športa. ${ }^{3}$

Sport koji se dugo vremena smatrao rekreativnim aktivnostima danas postaje komercijalna djelatnost koja donosi veliku dobit. Veći dio tog prihoda potječe iz različitih aktivnosti kao što su brendiranje, merchandising, licensing itd., koje uključuju iskorištavanje različitih prava intelektualnog vlasništva sportskih klubova.

Inovacije i kreativnost ključni su pokretači u svijetu sporta. U svakom sportskom polju, izumitelji i kreatori rade iza scene kako bi potisnuli granice, stvarajući nove mogućnosti za uživanje i za sportaše kako bi poboljšali njihovu izvedbu. Sport pokazuje intelektualno vlasništvo u akciji. Patenti potiču tehnološki napredak koji rezultira boljom sportskom opremom. Zaštitni znakovi, robne marke i dizajni pridonose jasnom identitetu događaja, timova i njihove opreme. Prava koja se odnose na autorska prava ostvaruju prihode potrebne za emitere da ulažu u skupo poduzimanje emitiranja sportskih događaja obožavateljima širom svijeta. Prava iz područja intelektualnog vlasništva osnova su sporazuma o licenciranju i trgovanju koji ostvaruju prihode za potporu razvoju sportske industrije. Intelektualno vlasništvo temelj je velikih komercijalnih mogućnosti koje nudi svijet sporta. Prava iz područja intelektualnog vlasništva (osobito patenti, zaštitni znakovi i prava emitiranja) i pravna zaštita koju daju pomažu osigurati ekonomsku vrijednost sporta. Ovo zauzvrat potiče rast sportske industrije, omogućava sportskim organizacijama financiranje visokih sportskih događaja i pruža sredstva za promicanje sportskog razvoja. Poslovne transakcije vezane uz sponzorstvo, merchandising, broadcasting i medijske ponude izgrađene su na pravima intelektualnog vlasništva. Sportska industrija ima sve veći utjecaj na svjetsko gospodarstvo, stvaranje radnih mjesta, ulaganje u javnu infrastrukturu i mobiliziranje resursa. Od sportske cipele do kupaćeg kostima i od teniskih reketa do nogometa, sportski tehnolozi primijenili su svoju genijalnost, kreativnost i stručnost kako bi razvili bolju i sigurniju opremu u potrazi za sportskom izvrsnošću. ${ }^{4}$

Stjecanjem prava intelektualnog vlasništva i strateškog korištenja, sportske organizacije i drugi vlasnici prava mogu zaštititi i povećati svoj potencijal za stvaranje prihoda.

Svjetska organizacija za intelektualno vlasništvo (WIPO) naglašava da su inovacije i kreativnost ključni pokretači u svijetu sporta. Tako novi izumi donose tehnološke prednosti u izradi sportske opreme (od tenisica, preko kostima za plivače, pa sve do teniskih reketa), a žigovi i industrijski dizajn kao prava intelektualnog vlasništva doprinose da se važni sportski događaji, timovi i natjecatelji jasno obilježe i time se na osobit način razlikuju jedni od drugih. Isto tako, da bi ljubiteljima sporta širom svijeta omogućili neposredno praćenje svih sportskih događaja,

3 Vidi Pojam sportskog prava, podatak na stranici: http://savremenisport.com/teorija-sporta/sport-ipravo/18/467/pojam-sportskog-prava; posjet 17. III. 2018.

4 Sport and Intellectual Property, podatak na stranici: http://www.wipo.int/ip-sport/en/, posjet 16. III. 2018. 
potrebna su značajna financijska, tehnička i organizacijska ulaganja organizacija za radiodifuziju, a povrat uloženih sredstava ostvarit će od prihoda od emitiranja sportskih događaja što im omogućava sustav zaštite autorskog i srodnih prava koja stoga imaju značajnu ulogu i u sportu. ${ }^{5}$

\section{IZUMI I PATENTI U SPORTU}

1. U zakonima se definicija izuma uobičajeno daje kriterijima patentibilnosti, odnosno navode se elementi koji izum čine patentibilnim. Ne daje se dakle definiciju izuma, nego se samo određuje biće patentibilnoga izuma. Samo onaj izum za koji se u zakonom određenom postupku utvrdi da predstavlja novost i doprinos znanstvenomu i tehničkomu fondu znanja ${ }^{6}{ }^{6}$ može, uz ispunjenje ostalih uvjeta, očekivati patentnu zaštitu. ${ }^{7}$ U patentnopravnoj teoriji izum se najčešće definira kao novo rješenje tehničkoga problema koje se može primijeniti u industriji. ${ }^{8}$ Izum predstavlja i predmet patenta. ${ }^{9}$

2. Patent ${ }^{10}$ je isključivo pravo priznato izumu koji nudi novo rješenje nekoga tehničkog problema. Patent se priznaje izumima koji se odnose na proizvod, postupak ili primjenu. ${ }^{11} \mathrm{U}$ najširem smislu patent podrazumijeva tehnološku inovaciju koja je pravno priznata i registrirana na području određene zemlje. ${ }^{12}$ Patentom se štiti izum koji čini novo tehničko rješenje određenoga problema, koji je rezultat stvaralačkoga rada, koji je tehnički izvodljiv i koji se može primijeniti u industrijskoj ili drugoj djelatnosti.

Patenti su, drži se, najbolji sustav pravne zaštite kojim se štite izumi. ${ }^{13}$ Međutim, patent nije jedini oblik zaštite izuma, ali je danas najrašireniji oblik zaštite koji uvijek imamo u vidu kad govorimo o koristi od zaštite izuma i svim važnijim pitanjima koja se odnose na izume. ${ }^{14}$ Umjesto prijave patenta, izumitelj može odlučiti da

5 Svjetski dan borbe protiv krivotvorina - 8. lipnja 2016., podatak na stranici: http://www.dziv.hr/hr/ novosti/svjetski-dan-borbe-protiv-krivotvorina---8.-lipnja-2016.,409.html, posjet 16. III. 2018.

6 O novosti izuma i kriterijima patentibilnosti detaljnije u: ČIZMIĆ, J., „Novost izuma“, Pravo u gospodarstvu, vol. 37, 1998., br. 4, str. 713-726; PARAĆ, Z., „Ciljevi patentne zaštite“, Privrednopravna praksa, 1989., br. 2; PARAĆ, Z., „Kriteriji patentibilnosti po Zakonu o zaštiti izuma, tehničkih unapređenja i znakova razlikovanja“, Informator, br. 3007, str. 19-20.

7 Usp. Inventions Patents and Patent Agents, London, 1992., str. 3.

8 Vidi u: PERIĆ, J., „Zaštita pronalazaka“, Jugoslovensko pronalazaštvo, 1987., br. 306, str. 9.

9 Tako u: PARAĆ, Z., „Opseg patentne zaštite“, Zbornik Pravnoga fakulteta u Zagrebu, 37, 1987. br. 2, str. 198.

10 Pojam i riječ ,,patent“ dolazi od latinske riječi litteras patentes, što znači javno pismo ili, drugim riječima, ono koje se objavljuje na takav način da bude pristupačno javnosti.

11 Podatak na stranici: http://www.dziv.hr/hr/intelektualno-vlasnistvo/patenti/sto-je-patent/

12 Vidi: FOLSOM, H. R. - GORDON, M. W. - SPANGOLE, J. A., Međunarodni trgovački poslovi - u sažetom obliku, Rijeka, 1998., str. 123.

13 Usp. Od ideje do profita, Zagreb, 1998., str. 26.

14 Tako u: MANIGODIĆ, M., Zaštita izuma u YU, EZ i USA, Beograd, 1991., str. 7. Patent je pravo koje fizičkoj ili pravnoj osobi pripada na temelju određenoga izuma. VERONA, A., Pravo industrijskoga vlasništva, Zagreb, 1978., str. 70. 
svoj izum zadrži kao poslovnu tajnu te ga sam upotrebljavati ne otkrivajući drugima detalje izuma. U tom se slučaju izlaže riziku da tko drugi dozna podatke o izumu i upotrijebi/zaštiti ga, ili da tko drugi sam dođe do takvoga izuma neovisno o prethodnom izumitelju. Izumitelj tada nema učinkovito pravno sredstvo za sprečavanje takve uporabe. Stoga je takav oblik zaštite preporučljivo upotrebljavati samo ako je razumno pretpostaviti da korisnik uvidom u sam proizvod ili postupak koji se temelji na izumu neće biti u stanju rekonstruirati tehničke detalje izuma te ako izumitelj poduzme sve raspoložive mjere da sačuva poslovnu tajnu. ${ }^{15}$

3. Sport, izumi i patenti. Jedan od najvećih izazova s kojima se suočava sport (tvrtke, organizacije, klubovi, sportski subjekti) jest potreba za inovacijama. Inovacije u suvremenom sportu nisu samo potreba, one su postale ključne (nužne) u njegovu daljnjem razvitku.

Danas je tisuće sportskih izuma zaštićeno patentima, od kojih su mnogi odobreni na temelju patentnih prijava podnesenih korištenjem WIPO-ovog PCT-sustava. Sportski timovi mogu patentirati sportsku metodu ili sportsku tehniku vježbanja i tako nastojati onemogućiti druge sportske ekipe da ih koriste. Ovaj pristup nudi potencijalnu značajnu konkurentsku prednost na športskom polju. Također, profesionalna sportska liga (ili druga organizacija koja upravlja može patentirati sustav i ustroj natjecanja. Primjerice, National Basketball Association („NBA“) nositelj je patenta za jednosatnu snimku te može spriječiti druge asocijacije (NCAA, ABA i dr.) da koriste njihov patent (tehniku). ${ }^{16}$

Nove i revolucionarne sportske tehnologije zaštićene su patentnim sustavom intelektualnog vlasništva. Od sportske cipele do kupaćeg kostima i teniskih reketa do nogometa, sportski tehnolozi primijenili su svoju genijalnost, kreativnost i stručnost kako bi razvili bolju i sigurniju opremu u potrazi za sportskom izvrsnošću. Ishod je bio: poboljšana izvedba; bolja, sigurnija i učinkovitija sportska oprema; precizno mjerenje performansi; mnoštvo načina na koje možete doživjeti sportske događaje bilo gdje i u bilo koje vrijeme. Ovaj vid ciklusa inovacija rezultirao je progresivnom zamjenom prirodnih materijala (drva, spona, crijeva, gume) koja je korištena za izradu razne sportske opreme širokim rasponom visoko sofisticiranih umjetnih materijala uključujući legure i polimere. Jača i lakša sportska oprema opremljena ovim visokotehnološkim materijalima omogućila je sportašima diljem svijeta da dosegnu nove visine postignuća, istodobno minimizirajući rizik od ozljeda i pomogla je sportašima da poboljšaju svoju izvedbu. Poboljšanja se kreću od prilagođenih i bržih dasaka za surfanje do udobnijih rukavica s protukliznim oblogama za nogometne vratare. Sportski napici, izgradnja mišića i prehrambeni dodaci, drugi su primjeri sportskih patenata. Zahvaljujući patentnom sustavu: proizvođači sportske opreme dobivaju financijski od inovacija, što zauzvrat povećava snagu i vitalnost industrije za dobrobit gospodarstva u cjelini; istraživači imaju pristup tehničkim informacijama koje mogu iskoristiti za poticanje inovacija i poboljšanja postojećih izbor/

15 Podatak na stranici: http://www.dziv.hr/hr/intelektualno-vlasnistvo/patenti/sto-je-patent/najbolji-

16 BAMBAUER, D., ,Legal responses to the challenges of sports patents“, Harvard Journal of Law \& Technology, Volume 18, Number 2, Spring 2005., str. 404. 
proizvoda; sportaši širom svijeta imaju koristi od inovacija u sportskoj opremi u poboljšanju vlastite učinkovitosti, smanjenju ozljeda i poticanju brzine oporavka nakon ozljeda; javnost ima korist od šireg asortimana vrhunske sportske opreme. ${ }^{17}$

Danas je gotovo nemoguće razaznati što je sve u sportu posljedica tehnološke inovacije, a što je ostalo od 'starog' sporta. Od kamera koje snimaju svaki kutak terena, preko modernih materijala koji omogućavaju sportašima da budu brži i spretniji pa sve do čipova u loptama koje prate njihovo kretanje i signaliziraju sucima. A sve je započelo još sredinom 19. stoljeća na konjskim trkalištima kada je postalo sve teže odrediti koji je konj prvi prešao ciljnu crtu. Tehnologija 'fotofiniša' prvi je put korištena 1912. godine na Olimpijskim igrama. Inovacije koje su se dogodile u posljednjih 10-15 godina u potpunosti su promijenile sportaše, treninge, natjecanja, ali i način na koji gledatelji prate sport. ${ }^{18}$

Primjerice, u nogometu, najvažnijoj sporednoj stvari na svijetu, često smo bili svjedoci nevjerojatnih sudačkih pogrešaka pa se zbog toga u sve više natjecanja uvodi tzv. „pomoćni video sudac" ili na engleskom "Video assistant referee", skraćeno "VAR". Osnovni je cilj VAR-a pružiti podršku sucima u postupku donošenja odluka. Nova videotehnologija koristi se samo u situacijama koje mogu odlučiti daljnji tok utakmice i njezino korištenje treba osigurati minimalne smetnje na sam tijek igre, odnosno pružiti maksimalne pogodnosti po pitanju regularnosti same utakmice. ${ }^{19}$

\section{III. ŽIG I SPORT}

1. Žig (engl. trademark) jest isključivo pravo priznato za znak koji služi za razlikovanje proizvoda i/ili usluga jedne osobe od ostalih osoba u gospodarskome prometu. ${ }^{20}$ Žig je u pravilu zaštićeni znak jedne pravne ili fizičke osobe kojoj pripada isključivo pravo da proizvode koji su označeni žigom stavlja u promet ili da se žigom koristi pri obavljaju uslužne djelatnosti. ${ }^{21}$ Žigom se štiti znak koji se može grafički prikazati, osobito riječi, uključujući osobna imena, crteže, slova, brojke, oblike

17 Sport and Technology, podatak na stranici: http://www.wipo.int/ip-sport/en/technology.html, posjet 16. III. 2018.

18 Tako ČIZMIĆ, M., Je li tehnologija pojela sport?, Podatak na stranici: https://www.tportal.hr/ tehno/clanak/je-li-tehnologija-pojela-sport-20130726. Posjet 18. II. 2019.

19 „Najpoznatije greške fudbalskih sudija u istoriji: U čuvenoj akciji u polufinali FIFA Svetskog kupa 1934. godine, za vodstvo Urugvaja protiv Jugoslavije od 2:1, učestvovao je jedan policajac, koji je loptu iz gol-auta vratio u igru i omogućio Anselmu da savlada "El Grande" Milovana Jakšića; Tzv. "Božija ruka" gol Diega Armanda Maradone 1986. godine, postignut rukom, koji je doneo prednost Argentini u meču protiv Engleske; Gol Džefa Harsta u 101. minutu finala FIFA Svetskog prvensta 1966. godine koji doveo Engleze u vođstvo od 3:2, gol za koji se ni dan danas ne može reći pouzdano da li je bio ili nije; Engleski sudija Pol Grejem na Mundijalu u Nemačkoj 2006. godine, na utakmici Australija - Hrvatska isključio je iz igre Josipa Šimunića tek pošto mu je pokazao treći žuti karton“. ŠKORIĆ, M., VAR tehnologija na FIFA Svetskom prvenstvu, Podatak na stranici: http://savremenisport.com/teorija-sporta/inovacije-usportu/5/525/var-tehnologija-na-fifa-svetskom-prvenstvu. Posjet 18. II. 2019.

20 Podatak na stranici: http://www.dziv.hr/hr/intelektualno-vlasnistvo/zigovi/.

21 Tako u: VERONA, A., Pravo industrijskoga vlasništva, Zagreb, 1978., str. 170. 
proizvoda ili njihova pakiranja, trodimenzionalne oblike, boje, te kombinacije svih navedenih znakova, ${ }^{22} \mathrm{i}$ koji je prikladan za razlikovanje proizvoda ili usluga jednoga sudionika u gospodarskome prometu od proizvoda ili usluga drugoga sudionika u gospodarskome prometu. ${ }^{23}$ Žig je znak koji služi i za identifikaciju roba i usluga, kao jamstvo određene kakvoće tih roba i usluga, te istovremeno predstavlja sredstvo oglašavanja. Žig je zapravo simbol reputacije proizvođača i kakvoće robe, odnosno usluga koje taj znak nose. ${ }^{24}$

2. Žigovi/brendovi ključni su za stvaranje poslovne vrijednosti, a sportsko područje nije iznimka. Jake marke određuju lojalnost kupaca i cijene premije, što predstavlja vrijednu imovinu koja potiče prihode i rast tvrtke.

Često dolazi do nedoumica oko razlike između termina žig i marka (brend). Ova dva koncepta, usprkos mnogim sličnostima, imaju različitu svrhu i prirodu, što se često previđa. Marka (brend) predstavlja ukupni skup signala koji prenose određeno značenje i stvaraju povoljnu sliku o proizvodu ili usluzi u svijesti potrošača kako bi ih privukli proizvodima ili uslugama određenog poduzeća. Drugim riječima, to je slika, skup obećanja koja poduzeće daje o svom proizvodu ili usluzi, a razvija se tijekom vremena, najčešće konzistentnom kvalitetom ili nekom drugom karakteristikom prepoznatom i cijenjenom od strane potrošača. S druge strane, žig predstavlja zaštićenu razlikovnu oznaku proizvoda ili usluge, koja je sastavni dio koncepta marke (brenda) i predstavlja pravno sredstvo koje štiti vlasnika marke (brenda) u slučaju neovlaštenog korištenja takve oznake. Također, žig predstavlja pravno sredstvo kod poslovnih transakcija vezanih uz određenu marku (brend) ${ }^{25}$

Izravni gubici ovog industrijskog sektora zbog prodaje krivotvorina na razini cijele Europske unije procjenjuju se na oko 500 milijuna eura godišnje $(6,5$ $\%$ ukupnih prihoda sektora). S time su povezani i gubici radnih mjesta, koji se procjenjuju na 2800 izgubljenih radnih mjesta unutar cijele Europske unije. ${ }^{26}$

Intelektualno vlasništvo legalno štiti sve na svjetskom tržištu; štiti kreme, kovčege, cipele, znanstvene ideje i mnogo više elemenata i predmeta. Za sportske zvijezde za nogomet, baseball, nogomet, tenis, golf, košarku i druge sportove zaista je važno zaštititi imidž i ime kako bi imali koristi od sportskog i marketinškog polja koristeći svoje ime kao zaštitni znak. Neki od primjera su nogometaši poput Messija, Beckhama i Jamesa Rodrigueza. Ovi igrači koriste svoju sliku za promociju losiona, odjeće, sportskih predmeta, pa čak i donjeg rublja, stvari koje nisu uvijek povezane s nogometom, ali da budu priznate, mogu prodati mnogo više od onoga što se plaća za igranje nogometa. Ljudi koji su uključeni u zabavu i sportsku industriju sada imaju mnogo više mogućnosti da zaštitite svoja imena i sliku kako bi dobili

22 Usp. BUKLJAŠ, I., Privredno pravo s osnovama prava, Zagreb, 1978., str. 406.

23 U tome smislu: ZLATOVIĆ, D., Žigovno pravo, Vizura, Zagreb, 2008., str. 39-40.

24 Vidi: DANILOVIĆ, T., „Zaštita prava na žig“, Privredno pravni priručnik, god. XVI, 1978., br. 8, str. 31 .

25 Žig ili marka (brend) - и čemu je razlika?, podatak na stranici: https://www.dziv.hr/files/File/ novosti/za-novinare/zig_ili_marka.pdf, posjet 16. III. 2018.

${ }_{26}$ Svjetski dan borbe protiv krivotvorina - 8. lipnja 2016., podatak na stranici: http://www.dziv.hr/hr/ novosti/svjetski-dan-borbe-protiv-krivotvorina---8.-lipnja-2016.,409.html, posjet 16. III. 2018. 
sponzorstva i koristi od poznatih tvrtki. Moraju postati jedinstveni ili učiniti nešto što im predstavlja kako bi ih mogli registrirati i zaštititi pravnim odredbama industrije intelektualnog vlasništva. ${ }^{27}$

Vrijednost žigova/marki/brendova sportskih tvrtki sve je veća. Tako je u 2017. godini brend „Nikea“ procijenjen na 29,6 milijardi dolara.

Što se sportskih događaja tiče, najvredniji je brend The Super Bowl koji je procijenjen na 663 milijuna.

Od sportaša na prvom je mjestu bio Roger Federer s iznosom od 37,2 milijuna dolara, ${ }^{28}$ ali ni brojni drugi vrhunski sportaši nisu zaostajali puno za njim po vrijednosti.

Svakako su posebno vrijedni žigovi sportskih klubova. Prema Forbesovoj listi vrijednost se procjenjuje kako slijedi: 1. Dallas Cowboys, 4,2 milijarde američkih dolara (NFL); 2. New York Yankees, 3,7 (MLB); 3. Manchester United, 3,69 (Soccer); 4. Barcelona, 3,64 (Soccer); 5. Real Madrid, 3,58 (Soccer); 6. New England Patriots, 3,4 (NFL); 7. New York Knicks, 3,3 (NBA); 8. New York Giants, 3,1 (NFL); 9. San Francisco 49ers, 3 (NFL); 9. Los Angeles Lakers, 3 (NBA); 11. Washington Redskins, 2,95 (NFL) itd..$^{29}$

Jedan od najpoznatijih sportskih brendova na svijetu ovih je dana okrenuo novu poslovnu stranicu. Slučajno ili namjerno, s obzirom na aktualnu političku situaciju, Nike je lansirao prvi sportski hidžab za žene koji bi se na tržištu trebao pojaviti na proljeće 2018. ${ }^{30}$

\section{ZAŠTITA OLIMPIJSKOG ZNAKA (SIMBOLA) ${ }^{31}$}

1. Olimpijske igre (engl. Olympic Games) međunarodni su športski događaj i veličanstveno višesportsko natjecanje koje se održava svake četiri godine. ${ }^{32}$ Olimpijske igre su natjecanja između športaša u pojedinačnim i ekipnim disciplinama. ${ }^{33} \mathrm{U}$ ekipnim disciplinama svaka država, sudionica Olimpijskih igara

27 The Power of a Name as a Registered Trademark in Sports, podatak na stranici: https://brlatina. com/blog/2015/the-power-of-a-name-as-a-registered-trademark-in-sports/, posjet 16. III. 2018.

28 Podatak na stranici: https://www.forbes.com/forbes/welcome/?toURL=https\%3A//www.forbes. com/pictures/59e62ee431358e542c03d5be/5-ncaa-final-four/\%23589593a15518\&refURL=\&referrer=, posjet 16. III. 2018.

29 BADENHAUSEN, T., Full List: The World's 50 Most Valuable Sports Teams 2017, podatak na stranici: https:/www.forbes.com/sites/kurtbadenhausen/2017/07/12/full-list-the-worlds-50-mostvaluable-sports-teams-2017/\#22a6bc774a05, posjet 16. III. 2018.

30 KOVAČIĆEK, T., Brend Nike je lansirao prvi sportski hidžab, podatak na stranici: https://www. gloria.hr/moda/novosti/brend-nike-je-lansirao-prvi-sportski-hidzab/5733919/, posjet 16. III. 2018.

31 Ovo poglavlje nastavnog materijala objavljeno je kod: ČIZMIĆ, J., „Zaštita olimpijskog znaka (simbola)“, Zbornik radova Pravnog fakulteta u Splitu, god. 47, 2010., br. 2, str. 257-273.

32 Pogrešno ih se naziva i Olimpijade, jer Olimpijadom je u staroj Grčkoj nazivano čitavo razdoblje između dviju Olimpijskih igara.

33 Olimpijske igre podijeljene su na ljetne i zimske športske događaje, i zimske i ljetne OI održavaju se svake četiri godine. Do 1992., održavane su iste godine, a od tada se održavaju razdvojeno svake dvije godine. 
(dalje - OI), smije poslati samo jednu ekipu. OI okupljaju športaše koje su imenovali njihovi nacionalni olimpijski odbori, a čije je prijave prihvatio Međunarodni olimpijski odbor. Športaši, ma kako poznati i kvalitetni bili, za razliku od natjecanja na nekoliko početnih OI, ne mogu se samoinicijativno prijavljivati za sudjelovanje na OI jer bi očito broj na taj način prijavljenih športaša bio nepodnošljivo velik. ${ }^{34}$ Brojne su organizacije uključene u organizaciju OI. One zajedno čine Olimpijski pokret. Pravila i načela po kojima postupaju uređena su Olimpijskom poveljom. Na čelu Olimpijskog pokreta je Međunarodni olimpijski odbor koji, ${ }^{35}$ kao svojevrsna Vlada, brine o predstojećim pitanjima i donosi važne odluke kao što su izbor grada domaćina OI, program Igara i dr. ${ }^{36}$ Olimpijski pokret koristi mnoga znamenja i simbole.

Moderne OI ne samo da su s vremenom napustile početno proklamirani športski amaterizam u korist profesionalizma, nego sve više postaju profitnom manifestacijom, a olimpijske oznake postaju predmetom marketinškog i tržišnog interesa, ${ }^{37}$ često na način da se olimpijski simboli koristi suprotno odredbama Olimpijske povelje, Nairobijskog ugovora o zaštiti olimpijskog simbola, te drugih međunarodnih i nacionalnih propisa kojima se štite olimpijski simboli i dogođaji koji se vezuju uz održavanje OI.

Naime, vezano za športska natjecanja i događanja javlja se relativno nova pojava nazvana ambush marketing (marketing iz zasjede) i svodi se na (zlo)upotrebu velikih športskih i drugih događaja u reklamne svrhe, bez plaćanja odgovarajućih nadoknada. ${ }^{38}$ Što se Olimpijskih igara tiče, termin „Ambush Marketing” uključuje

34 Podatak na stranici http://hr.wikipedia.org/wiki/Olimpijske_igre.

35 „Olimpijske igre ekskluzivno su vlasništvo MOO-a koji posjeduje sva prava koja se na njih odnose, a posebno, prava koja se odnose na njihovu organizaciju, korištenje, izvještavanje, snimanje, predstavljanje, reprodukciju, pristup i širenje u svakom obliku i svim sredstvima ili mehanizmom, bilo da on postoji ili će se razviti u budućnosti. MOO utvrđuje uvjete pristupa i korištenja podataka koji se odnose na olimpijske igre te na natjecanja i športske rezultate olimpijskih igara. Sva zarada dobivena proslavom olimpijskih igara koristi se za razvoj olimpijskog pokreta i športa“ (Olimpijska povelja, članak 11.).

36 Međunarodni olimpijski odbor (eng. IOC od International Olympic Commitee, franc.: Comité International Olympique, CIO, dalje - MOO) međunarodna je športska organizacija sa sjedištem u Švicarskoj, u gradu Lausannei. Osnovana je 23. lipnja 1894. na kongresu u Parizu, pod idejnim vodstvom baruna Pierrea de Coubertina. Njegova je ideja bila oživjeti oblik natjecanja poznat u staroj Grčkoj po modelu športskog međunarodnog natjecanja najvišeg ranga. Na istom je kongresu odlučeno da će domaćin I. OI biti Atena, te je za godinu održavanja odabrana 1896.

37 Vidi KENNY \& SAYWELL, Marketing and the Sydney 2000 Olympic Game, Intellectual Property Asia, No 12, 1999., str. 27-29.

38 Tako je Nike, primjerice, na Olimpijadi u Atlanti 1996. godine na svim transportnim punktovima u gradu i oko borilišta dijelio kape koje su onda gledatelji nosili na tribinama, na zgražavanje i očaj Reeboka, jednog od službenih sponzora OI. Kao primjere ambush marketinga mogli bismo navesti i sljedeće: 1992. Nike je sponzorirao press-konferencije američke košarkaške reprezentacije. Pamti se i kako je Michael Jordan primio zlatnu medalju i njome pokrio logo Reeboka, službenog sponzora; 1994. nakon inzistiranja službenog sponzora, kompanije Visa, da se kreditne kartice konkurenta American Expressa ne primaju u olimpijskom selu, Amex se sjetio da u svojim reklamama podsjeti Amerikance da im ne treba „viza” da bi putovali na Zimske olimpijske igre u Norveškoj; 2000. australijski avioprijevoznik Quantas Airlines je pokrenuo slogan Duh Australije, sumnjivo sličan službenom sloganu Olimpijade u Sydneyju: Podijelimo duh, na veliko nezadovoljstvo službenog sponzora, avioprevoznika Ansett Air. Vidi Ambush Marketing, „biznis.ba“, http://www.biznis.ba/index.php?option=com_content\&task=view\&id=3709\&Itemid=59, stranica učitana: 18,05 /13. II. 2010. 
bilo kakav planirani ili neplanirani pokušaj treće strane da kreira, izravno ili neizravno, lažnu ili neautoriziranu komercijalnu vezu s Olimpijskim pokretom ili OI, s ciljem prepoznavanja i dobivanja beneficija koje se odnose na olimpijske sponzore. Službeni olimpijski partneri/sponzori osiguravaju značajne financijske izvore Olimpijskom pokretu. U smislu njihove podrške oni uživaju određena ekskluzivna marketinška prava koja su u svezi s kategorijom datog proizvoda u okviru specifičnog teritorija. Ekskluzivnost je esencijalna karakteristika olimpijskog marketinga i vrijednost prava dodijeljenih olimpijskim sponzorima u izravnoj je svezi s mogućnošću olimpijskih tijela da zaštite takvu ekskluzivnost. Razni subjekti provode aktivnosti ambush marketinga ponajviše radi toga da bi ostavili dojam kako su baš oni olimpijski sponzori te da bi zbunili javnost glede toga tko je stvarni sponzor. U proteklim godinama zapaženo je da ambush marketing ima tendenciju rasta u razdoblju prije i za vrijeme OI. ${ }^{39}$

2. Olimpijski pokret koristi brojna znamenja i simbole, od kojih mnoga prezentiraju ideje i ideale koje je Coubertin imao u svojim vizijama. Razvidno je da se pojam „olimpijski simbol“ u stručnoj literaturi i u široj javnosti terminološki i sadržajno različito tumači i percipira. Naime, nekada se taj pojam (u užem smislu) smatra i koristi kao sinonim za olimpijski znak (krugove, prstenove). Drugom prilikom, a posebno kad se navodi u prvom licu množine - „olimpijski krugovi“, taj pojam koristi se (u širem smislu) kao nadređeni pojam za brojna službena olimpijska znakovlja: olimpijski znak (krugovi): olimpijska zastava; olimpijska vatra; olimpijska baklja; olimpijski moto (geslo), olimpijski pozdrav; olimpijska prisega; olimpijska himna; olimpijske medalje; pa čak i olimpijske maskote, olimpijski slogani, olimpijski plakati i sl. Neki od olimpijskih simbola koriste se više za vrijeme trajanja olimpijskih natjecanja (primjerice, olimpijska vatra, olimpijska prisega, olimpijski pozdrav), a neke se može vidjeti i prije i nakon natjecanja (primjerice, olimpijski znak i olimpijska zastava). Olimpijski simboli nalaze se i na olimpijskim markama (Olympic Stamps) ${ }^{40}$ olimpijskim značkama (Olympic Badges), olimpijskim bedževima (Olympic Buttons), odjevnim predmetima i sl.

Za sve olimpijske simbole zajedničko je da uživaju veći ili manji stupanj pravne zaštite, kako od strane tijela MOO-a, tako i od strane nacionalnih olimpijskih odbora (dalje - NOO) i drugih državnih organa država članica i države domaćina Olimpijskih igara.

39 Vidi Ambush Marketing, ICC Television \& Marketing Services, podatak na stranici okbih.ba/doc/ Sta\%20je\%20Marketing\%20iz\%20Zasjede.doc.

40 MOO potiče, u suradnji s NOO-ima odgovarajućih zemalja, upotrebu olimpijskog simbola na poštanskim markama, koje u suradnji s MOO-om izdaju nadležne nacionalne vlasti; upotrebu olimpijskog simbola u tu svrhu može odobriti ovisno o uvjetima Izvršnog odbora MOO-a (Olimpijska povelja, čl. 17. t. 5.). 


\section{PRAVNA ZAŠTITA IMIDŽA SPORTAŠA ${ }^{41}$}

1. Imidž (engl. image) možemo definirati kao sveobuhvatnost stila i poimanja neke osobe, odnosno sveobuhvatnost originalnih karakteristika neke osobe. ${ }^{42}$ „Imidž“ možemo definirati i kao svaku oznaku koja određuje pojedinog čovjeka, kao što je to ime, lik, glas, potpis, karakter i druge distinktivne osobine prema kojima se konkretna osoba razlikuje od drugih ljudi, ${ }^{43}$ ali i kao spoznajnu sliku o poduzeću, osobi, procesu ili situaciji koju pojedinac oblikuje na temelju cjelokupnog prethodnog iskustva, stavova, mišljenja i predodžbi koje su više ili manje usklađene sa stvarnim obilježjima. ${ }^{44}$

Imidž predstavlja ukupnost vanjskoga dojma koji netko - izgledom, odijevanjem, ponašanjem - ostavlja, ili nastoji ostaviti, odnosno imidž je percepcija koju ljudi imaju o vanjskim, vidljivim osobinama neke osobe (ali i tvrtki i robnih marki). ${ }^{45}$ Sam po sebi izraz ,imidž“ podrazumijeva emocionalnu sliku, tj. predodžbu o nekoj osobi. To je zbir uvjerenja, ideja i impresija koje drugi imaju u odnosu na njih. Imidž može biti pozitivan, neutralan ili negativan. Imidž je ujedno i poruka koju šaljemo drugima. Osobni imidž je komunikacija i to ona dominantna - neverbalna. Neverbalnu komunikaciju čine tzv. govor tijela uz kontakt očima, stav, geste, glasovne ekspresije, izraz lica, odjeća, obuća, dodaci, simboli, make up, mirisi... dakle sve ono što predstavlja imidž osobe. Imidž je naš osobni marketing koji nam pomaže ili odmaže u razvoju karijere. ${ }^{46}$ Stoga su ljudi počeli paziti na odijevanje, hod, govor, geste kako bi stvorili dopadljivu javnu pojavnost. Kao takav, imidž je prvenstveno povezan s pojmovima: percepcija, iskustvo, uvjerenja, osjećaji. ${ }^{47}$

Predodžba koju imamo o nekom sportašu ponekad je dominantnija od ostvarenih sportskih rezultata, jer slika koju javnost stvara o sportašu nastaje ne samo temeljem sportskog uspjeha, već i njegove prisutnosti u medijima, ponašanja, odijevanja i drugih čimbenika koji nisu u izravnoj svezi sa sportskim rezultatima. Na ostavljanje prvog dojma utječe i frizura. ${ }^{48}$ Mogli bismo kazati da imidž kao pojam u sebi sadrži niz izvornih karakteristika neke osobe pa i sportaša, kao što su ličnost/lik/ slika, ime i prezime, nadimak, pseudonim, glas, ali i druge karakteristike određene

41 Podloga za ovaj dio nastavnog materijala jest poglavlje: ČIZMIĆ, J. - KAČER, H., „Pravna zaštita imidža sportaša u Republici Hrvatskoj“, u knjizi: Hrvoje Kačer et al, Sportsko pravo, Pravni fakultet Sveučilišta u Splitu, Split, 2018., str. 379-423.

42 Tako FILIPOVIĆ, M., Rječnik stranih riječi, Zagreb, 1988., str. 156.

43 Vidi BALCARCZYK, J., ,Sport image rights - a comparative overview“, Zbornik radova Pravnog fakulteta u Splitu, god. 47, 2010., broj 2, str. 328.

44 Usp. MARUŠIĆ, S., Upravljanje markom na primjeru nogometnog kluba Manchester United, Diplomski rad, Split, 2012.

45 Podatak na stranici: http://www.spem.si/hrv/Aktivnosti/Istrazivanja/Mjerenje-imidza-/.

46 V. K., Poslovni imidž menadžera i poduzetnika, podatak na stranici: MojPosao.net - Poslovni imidž menadžera i poduzetnika http://www.moj-posao.net/Vijest/60816/Poslovni-imidz-menadzera-ipoduzetnika/\#ixzz3IJKIhN9O.

47 Vidi SOFTIĆ, L., Vizualni identitet $i$ brand/iranje, podatak na stranici http://savjetnik.ba/wpcontent/uploads/2014/08/Vizualni-identitet-i-brandiranje.pdf. (22. XII. 2017.).

48 Sunčica Bartoluci - Diana Tomić, Više od riječi - neverbalna komunikacija trenera i sportaša (1. dio), str. 8-9, http://ukth.hr/media/files/4-10-bartoluci-2-2013.pdf. (22. XII. 2017.). 
osobe koje tu osobu čine prepoznatljivom u javnosti (primjerice, način hoda, stil odijevanja, frizura, tetovaža i sl.). Što se sportaša tiče, posebno bismo ukazali na neke karakteristike imidža športaša koje su u novije vrijeme značajno zastupljene kod formiranja imidža pojedinih športaša, odnosno njihove identifikacije i individualizacije u očima javnosti, a, s druge strane, zaštita tih karakteristika imidža u hrvatskom pravu nije izrijekom uređena pravnim propisima niti je (značajnije) zastupljena u sudskoj i upravnopravnoj praksi.

Danas se sve više susrećemo sa složenim izazovom kreiranja profesionalnog imidža sportaša, a pri tome je postalo jasno da, ako sportaš osobno ne poduzme mjere i aktivnosti za izgradnju vlastitog profesionalnog imidža, okolina će to sigurno uraditi. U tom smislu profesionalni imidž sportaša je skup kvaliteta i karakteristika koji predstavljaju jednu osobu u očima za nju relevantnih osoba - trenera, sponzora, sportskog auditorija i javnosti uopće. ${ }^{49}$

S obzirom na to da je sport djelatnost koju prati iznimno široki krug građana i medija, gospodarstvenici su uvijek nastojali marketinški iskoristiti popularnost i sveprisutnost sporta u najširoj javnosti, kako bi svoje proizvode i usluge plasirali na tržištu dovodeći ih, izravno ili posredno, u svezu s imidžom sportaša. Tako se, primjerice, Adidas obvezao košarkašu Derricku Roseu na temelju ugovora o angažiranju u promoviranju sportske opreme isplatiti 260 milijuna dolara, a Le Bron James potpisao je ugovor vrijedan 90 milijuna dolara kojim se obvezao pružati usluge reklamiranja sportske opreme Nike. ${ }^{50}$

Zbog toga se i ukazala potreba pravne zaštite imidža sportaša od neovlaštenog korištenja tog imidža u bilo koje svrhe, pa i u marketinške. Upotreba imena ili slike poznatih sportaša ili sportskih ekipa na proizvodima ili prilikom pružanja usluga, ima za cilj izvući beneficije što ih oni povlače za sobom kroz identifikaciju potrošača s tim osobama. Sport je postao društveni i kulturni fenomen suvremenog društva. Športska natjecanja privlače velik broj ljudi tako da je sport zbog svoje masovnosti i atraktivnosti postao i poduzetnički zanimljiv. ${ }^{51} \mathrm{Ne}$ samo navijači, nego i mediji prate sportaše i izvan sportskih natjecanja, njihov privatni i obiteljski život, detaljno istražujući i objavljujući najintrigantnije i za sport potpuno nebitne detalje iz života sportaša. U tom smislu dio sportaša stekao je prepoznatljivi imidž upravo na temelju podataka o svom privatnom i obiteljskom životu, svakako u većoj mjeri negoli na temelju svojega sportskog djelovanja.

Sportska ostvarenja i rezultati čine vrhunske sportaše komercijalno atraktivnima za velike korporacije, koje na taj način žele prenijeti dio imidža sportaša, njegove uspjehe i rezultate na sebe i time dodatno promoviraju vlastiti proizvod, uslugu ili

49 MARJANOVIĆ, M., Strategije za izgradnju profesionalnog sportskog imidža, Savremenisport. com, 12. VII. 2014., http://savremenisport.com/teorija-sporta/sportski-marketing/9/260/strategije-zaizgradnju-profesionalnog-sportskog-imidza.

50 Tako kod BAGRA, S., „Korišćenje ljudskog obličja u komercijalne svrhe“, Uslužno pravo, Kragujevac, 2013. str. 80.

51 Podatak na stranici http://www.pup.hr/program_sport_hr.html, (22. XII. 2017.). 
brend. S druge strane, i sportaši u tome nalaze svoj interes jer su reklamni ugovori, više nego li sportski nastupi, učinili mnoge sportaše milijunašima. ${ }^{52,53}$

2. Žig je zaštićeni znak neke pravne ili fizičke osobe kojoj pripada isključivo pravo da proizvode koji su označeni žigom stavlja u promet ili da se žigom koristi pri obavljaju uslužne djelatnosti. Žig je znak koji služi za identifikaciju roba i usluga, kao jamstvo određene kakvoće tih roba i usluga, te istovremeno predstavlja sredstvo oglašavanja, pa zapravo predstavlja simbol reputacije proizvođača i kakvoće roba, odnosno usluga koje taj znak nose..$^{54}$

Pojedini gospodarski subjekti žele na tržištu iskoristiti fenomen popularnosti nekog športaša kod potrošača u komercijalne svrhe, označavajući svoje proizvode imenima, nadimcima ili slikama popularnih športaša. Poznati su primjeri označavanja sportske obuće ili sportskih rekvizita imenima ili nadimcima popularnih športaša (Sting, Air).

Sve države, u pravilu, propisuju mogućnost zaštite imidža sportaša nekim od prava iz područja industrijskog vlasništva, a posebno žigovnim pravom. Pri tome su moguća odstupanja u pogledu opsega originalnih osobina nekog športaša koje mogu bite predmet zaštite (primjerice, cjelokupni imidž ili samo osobno ime i prezime i slika).

U pravu Republike Hrvatske imidž sportaša moguće je zaštititi žigom u skladu s odredbama Zakona o žigu (Narodne novine, broj 173/2003, 76/2007, 30/2009, 49/2011, dalje - ZOŽ). Odredbom čl. 2. ZOŽ-a propisano je da se kao žig može zaštititi svaki znak koji se može grafički prikazati, osobito riječi, uključujući osobna imena, crteže, slova, brojke, oblike proizvoda ili njihovo pakiranje, trodimenzionalne oblike, boje, kao i kombinacije svih naprijed navedenih znakova,

52 „Angažiranje sportaša u reklamama stara je stvar, još otkad je Red Rock Cola angažirala bejzbolsku zvijezdu Babea Rutha u reklami za osvježavajuće piće. Primjerice, 2008. Tiger Woods je ubrao 5,95 milijuna dolara od nastupa na golferskim terenima, dok je marketinški angažman naplatio oko 100 milijuna dolara, nogometaš David Beckham (Adidas, Gillette, Pepsi, Armani), košarkaš LeBron James (Nike, Sprite, Vitamin Water), igrač golfa Phil Mickelson (Barclay, Rollex, Callaway), motorist Valentino Rossi (enegetsko piće Monster), vozač Formule Kimi Räikkönen (satovi Tag Heuer), igrač američkog nogometa Peyton Manning (Reebok, Gatorade, Sprint i MasterCard), boksač Manny Pacquiao (Nike, McDonald's, Alaxan), vozač NASCAR Dale Earnhardt Jr. (Adidas, Sony, Chevrolet). Janicu Kostelić je, sasvim logično, pod svoje okrilje uzeo i proizvođač mineralne vode Jamnica te Hypo Alpe-Adria, Renault i OMV Istrabenz. Jamničin konkurent na tržištu mineralne vode, Podravka, angažirao je Gordana Kožulja i Branku Vlašić za promidžbu Studene i Studenca“. PODNAR, O., Tijelo kao reklamni pano, podatak na stranici: http://www.poslovni.hr/after5/tijelo-kao-reklamni-pano-129452\#., (22. XII. 2017.).

53 Ronaldo ima ugovore s kompanijama kao što su Emirates, Nike, Samsung Electronics i Toyota Motor. Također, najpraćeniji je sportaš na društvenim mrežama. LeBron James ima ugovore s Nikeom, McDonald'som, Coca-Colom, Upper Deckom te drugima. Lionel Messi ima ugovore s kompanijama kao što su Adidas, Electronic Arts, Gillette, Herbalife, PepsiCo i Turkish Airlines. Kobe Bryant potpisao je ugovore s tvrtkama Turkish Air, Lenovo, Hublot, Nike i Panini itd. Tko su najplaćeniji svjetski sportaši? http://liderpress.hr/biznis-i-politika/svijet/floyd-mayweather-je-najplaceniji-igrac-u-2014-godini/, XII. 2017.).

54 Šire o žigovnom pravu u Republici Hrvatskoj kod ČIZMIĆ, J. - ZLATOVIĆ, D., Komentar Zakona o žigu, Zagreb, 2002.; CIZMIĆ, J., Ogledi iz prava industrijskog vlasništva, Split, 1998.; ZLATOVIĆ, D., Žigovno pravo, Zagreb, 2008., ČIZMIĆ, J. - BOBAN, M. - ZLATOVIĆ, D., Nove tehnologije, intelektualno vlasništvo i informacijska sigurnost, Pravni fakultet Sveučilišta u Splitu, Split, 2016. 
pod uvjetom da su prikladni za razlikovanje proizvoda ili usluga jednog poduzetnika od proizvoda i usluga drugog poduzetnika.

Prema odredbi čl. 64. st. 4. ZOŽ-a, na temelju podnesenoga prigovora znak neće biti registriran između ostalog i ako bi njegova uporaba vrijeđala neko od ranijih prava, ${ }^{55}$ kao što je a) pravo na osobno ime, i b) pravo na osobnu sliku. Svakako, pravo na osobno ime i pravo na osobnu sliku mora biti stečeno, odnosno mora postojati na datum raniji od datuma prijave (priznatog prvenstva) žiga. ${ }^{56}$

2.1. U postupku stjecanja žiga opseg zaštite ranijeg prava na osobno ime i prezime i na osobnu sliku treba procjenjivati u odnosu na nacionalne propise koji ta prava uređuju, a ne analognom primjenom ZOŽ-a.

Osobno ime u pravu označava ono ime koje se koristi za označavanje i razlikovanje osoba, a sastoji se, prema hrvatskim propisima, od imena (prvog ili vlastitog) i prezimena (drugog ili obiteljskog imena). Svaki čovjek ima pravo na ime kao oblik identifikacije i individualizacije određene, neponovljive osobnosti.

Pravo na osobno ime sastavni je dio i pojavni aspekt prava osobnosti (ličnosti). I u građanskopravnoj teoriji prevladava stajalište da pravo na ime treba svrstati u sustav prava ličnosti (osobnosti). Pritom nije potpuno samostalno, već je uključeno u kompleks prava na osobni identitet kojim se osim imena štite i druge osobne oznake pojedinca, znakovi njegove individualizacije. Kao i ostala prava ličnosti (osobnosti), pravo na ime apsolutno je pravo. Prema trećim osobama djeluje ponajprije kroz negativan sadržaj, tj. kroz zabranu nedopuštene uporabe imena. Nadalje, riječ je o neprenosivom pravu koje također ne može zastarjeti. Pravo na osobno ime pravo je strogo osobne prirode s obzirom na to da traje dok je živ i nositelj imena. Smrću fizičke osobe gasi se, no nasljednici i dalje mogu zaštititi pokojnikovo ime kroz odredbe o postmortalnoj zaštiti ličnosti. ${ }^{57}$

Povreda prava osobnosti prava na osobno ime predstavlja neimovinsku štetu. Može se počiniti, primjerice, kad se koristi ime poznatog športaša i na taj način privlači publiku da prisustvuje športskom natjecanju, iako se zna da taj športaš neće moći nastupiti. ${ }^{58}$ Do povrede prava osobnosti športaša na osobno ime može

55 Pod pojmom „ranije pravo“ razumijevaju se prava stečena na datum koji je raniji od datuma prijave za registraciju žiga ili, ako je zatraženo pravo prvenstva, od datuma prava prvenstva zatraženog u prijavi (ZOŽ, čl. 6. st. 5.).

56 Relativni razlozi za isključenje mogućnosti stjecanja žiga koji sadrži osobno ime ili sliku neke osobe, u koncepciji se bitno razlikuju od rješenja predviđenih u ranije važećem Zakonu o industrijskom vlasništvu Republike Hrvatske (Službeni list SFRJ, broj 34/1981, 3/1990 i 20/1990, te Narodne novine, broj 53/1991 do 33/2002, dalje - ZIV), jer se više ne radi o razlozima koji su otklonjivi pristankom određenog ovlaštenika, nego o razlozima zbog kojih može (ali i ne mora) doći do uskrate zaštite takvog znaka. Naime, prema odredbi čl. 30. st. 2., 3. i 4. ZIV-a, lik ili ime neke osobe bilo je moguće zaštititi samo po pristanku te osobe, dok je lik ili ime umrle osobe bilo moguće zaštititi samo po pristanku bračnog druga i djece umrlog, a ako su bili živi roditelji umrlog, bio je potreban i njihov pristanak. Lik ili ime povijesne ili druge znamenite osobe moglo se zaštititi uz dozvolu nadležnog organa. 121-138.

57 Usp. DROPULIĆ, J., „Pravo na osobno ime“, Hrvatska javna uprava, god. 6., (2006.), br. 2, str.

58 Vidi kod CRNIĆ, I., „Prava osobnosti i neimovinska šteta u športu“, u knjizi Uvod u športsko pravo, Zagreb, 2009., str. 172. 
doći, primjerice, i neovlaštenim davanjem nekoj trgovačkoj radnji ili ugostiteljskom objektu imena nekog poznatog športaša radi privlačenja klijenata i stjecanja veće zarade.

2.2. S obzirom na to da postupku stjecanja žiga opseg zaštite ranijeg prava na osobno ime i prezime treba procjenjivati u odnosu na nacionalne propise koji ta prava uređuju, a ne analognom primjenom ZOŽ-a, treba kazati da se postupak određivanja i zaštita osobnog imena hrvatskih državljana uređuje Zakonom o osobnom imenu (Narodne novine, broj 69/92). Prema odredbama toga Zakona, osobno ime sastoji se od imena i prezimena. Svaki građanin ima pravo i dužnost služiti se svojim osobnim imenom (čl. 2.). Osoba koja upotrijebi tuđe osobno ime kao svoje, kaznit će se za prekršaj novčanom kaznom ili kaznom zatvora do 15 dana (čl. 14.).

U Republici Hrvatskoj pravo na osobno ime, kao i druge zaštićene osobnosti čovjeka, ima temeljno pravno uporište u Ustavu koji odredbom čl. 22/1. jamči zaštitu čovjekove osobnosti na način da jamči da je čovjekova sloboda i osobnost nepovrediva. Nadalje, odredbom čl. 35. Ustava ,svakom se jamči štovanje i pravna zaštita njegova osobnog i obiteljskog života, dostojanstva, ugleda i časti“. Ocjenjujući u jednom predmetu je li navedeni članak Ustava mjerodavan u konkretnom slučaju, budući da ne sadrži izričite odredbe o osobnom imenu, Ustavni sud je pošao od definicije osobnog imena kao oznake identiteta fizičke osobe. Osim oznake identiteta fizičke osobe kao nositelja prava i obveza u pravnom prometu, osobno ime predstavlja i način identificiranja osoba unutar njihovih obitelji i zajednice, a za pojedinca pravo na osobno ime njegovo je osobno pravo. U tom smislu zaštita osobnog i obiteljskog života, dostojanstva, ugleda i časti, zajamčena i zaštićena Ustavom svakako se odnosi i na osobno ime. To znači da svatko ima pravo na osobno ime, da se ono radi zaštite njegova nositelja i pravne sigurnosti upisuje u određene javne knjige, da svatko može (a i dužan je) njime se služiti, da se nikoga ne može prisiljavati da mijenja osobno ime iz etničkih, jezičnih, političkih, kulturnih ili bilo kojih drugih razloga. ${ }^{59}$

No osnova za sudsku zaštitu osobnog imena ipak je odredba čl. 1100. Zakona o obveznim odnosima. Tim je člankom propisano da će ,u slučaju povrede prava osobnosti sud, ako nađe da to težina povrede i okolnosti slučaja opravdavaju, dosuditi pravičnu novčanu naknadu, nezavisno od naknade imovinske štete, a i kad nje nema“. Pri odlučivanju sud treba voditi računa o jačini i trajanju duševne boli koju je uzrokovala neovlaštena uporaba osobnog imena te o cilju kojemu služi ta naknada. ${ }^{60}$ Kao što sportaš može odobriti da se njegovo ime i prezime koristi u komercijalne svrhe, ima jednako pravo i zabraniti uporabu svoga imena i prezimena u komercijalne, ali i bilo koje druge svrhe. Tako je obitelj poznatog hrvatskoga sportaša pok. Mate Parlova zabranila Kazalištu Ulysses da svoju predstavu nazovu „Mate Parlov“, jer su upravo „, ciljem sprečavanja nekontroliranog i protupravnog

59 Navedeno stajalište Ustavni sud je zauzeo u odluci broj: U-III-484/1998 od 11. srpnja 2007. godine, Narodne novine, broj 87/07.

60 Tako i šire kod RADOLOVIĆ, A., „Prava ličnosti u građanskom pravu Hrvatske“, Vladavina prava, br. 1, Zagreb, 1998., str. 82; GAVELLA, N., Osobna prava, I. dio, Zagreb, 2000., str. 30. 
korištenja imena i prezimena Mate Parlov, prijavili i zaštitili u Državnom zavodu za intelektualno vlasništvo verbalni žig MATE PARLOV, te da za korištenje imena i prezimena Mate Parlov treba ishoditi suglasnost obitelji koja je vlasnik zaštićenog djela i lika Mate Parlov“. Zbog toga je naziv predstave promijenjen u „Doručak šampiona". ${ }^{61}$

Zakon o zaštiti osobnih podataka (Narodne novine, broj 103/03, 118/06, 41/08) uređuje zaštitu osobnih podataka o fizičkim osobama te nadzor nad prikupljanjem, obradom i korištenjem osobnih podataka u Republici Hrvatskoj, u svrhu zaštite privatnog života i ostalih ljudskih prava i temeljnih sloboda u prikupljanju, obradi i korištenju osobnih podataka. Osobnim podatkom smatra se svaka informacija koja se odnosi na identificiranu fizičku osobu ili fizičku osobu koja se može identificirati, odnosno na osobu čiji se identitet može utvrditi izravno ili neizravno, posebno na osnovi jednog ili više obilježja specifičnih za njezin fizički, psihološki, mentalni, gospodarski, kulturni ili socijalni identitet (čl. 2.).

Treba kazati da su sportaši iz sportskih, komercijalnih ili nekih drugih razloga svojevoljno zamijenili osobno ime, a po novom imenu su bili/ostali prepoznatljivi i više zapamćeni nego li po prvotnom osobnom imenu. Tako je, nakon što je 1964. senzacionalno porazio Sonnyja Listona, Cassius Clay šokirao javnost objavom kako se pridružio Naciji islama te promijenio ime $u$, sada legendarno, Muhammad Ali. ${ }^{62}$ I legendarni američki košarkaš izjavio je kako je rođen kao Lew Alcindor, a da je od 1971. Kareem Abdul-Jabbar. „Prelaz sa Lewa na Kareema nije bila puka promjena naziva brenda slavne ličnosti, već transformacija srca, uma i duše"“. ${ }^{63}$ Igrača Cincinnati Bengalsa s brojem 85 Chada Javona Johnsona vodstvo NFL-a kaznilo je 2006. godine sa 30.000 dolara kazne zbog promjene imena, odnosno zbog toga što je u zapisniku pisalo Chad Javon Johnson, a njemu na leđima "Ocho Cinco". Međutim, 2008. godine igrač je promijenio ime i službeno je postao Chad Ochocinco. Ili Chad 85. ${ }^{64}$ Košarkaš LA Lakersa Ron Artest 2011. promijenio je ime u Mitta World Peace. Time je postao četvrti NBA-igrač koji je promijenio svoje ime. Prije njega to su učinili Kareem Abdul-Jabbar (prije se zvao Lew Alcindor), Bison Dele (Brian Williams) i Mahmud Abdul-Raff (Chris Jackson) ${ }^{65}$ I hrvatski košarkaški reprezentativac Damir Omerhodžić promijenio je 2004. godine prezime i postao je Damir Markota. UFC-ov borac Jon Koppenhaver u početku karijere na osobnu iskaznicu stavio je novo ime - Ratni Stroj (War Machine).

61 Vidi BEGIĆ, V., “Mate Parlov” postao “Doručak šampiona”, podatak na stranici: http://www. novilist.hr/novilist_public/layout/set/print/Kultura/Mate-Parlov-postao-Dorucak-sampiona. (22. XII. 2017.).

62 Tako Znate li zašto je Cassius Clay postao Muhammad Ali?, http://www.slobodnadalmacija.hr/ sport/ostalo/clanak/id/314636/znate-li-zasto-je-cassius-clay-postao-muhammad-ali. (22. XII. 2017.).

63 Usp. Kareem Abdul-Jabbar: Zašto sam prešao na islam, podatak na stranici: http://balkans. aljazeera.net/vijesti/kareem-abdul-jabbar-zasto-sam-presao-na-islam. (22. XII. 2017.).

64 Vidi Promijenio si je ime u broj: Moje ime je 85. Chad 85..., podatak na stranici: https://www.24sata. $\mathrm{hr} / \mathrm{sport} /$ promijenio-si-je-ime-u-broj-moje-ime-je-85-chad-85-183006 - 24sata.hr. (22. XII. 2017.).

65 Usp. Zločesti američki dečko sasvim je poludio, podatak na stranici: http://net.hr/sport/kosarka/ zlocesti-americki-decko-sasvim-je/. (22. XII. 2017.). 
Osobno ime promijenili su neki sportaši i prije nego li su se počeli aktivno baviti vrhunskim sportom. Nogometaš Intera, prvaka Europe, Walter Samuel nekad se prezivao Lujan. Poznati nogometaš Marcel Desailly rođen je kao Odenkea Abbeya, a posvojitelji su mu promijenili ime po kojemu je postao svjetski poznati nogometaš itd.

Fuahea Semi (sanjkanje) zbog nedostatka financijskih sredstava za odlazak na Olimpijadu u Sočiju odrekao se svoga imena i uzeo je ime svoga sponzora te se danas službeno zove Bruno Banani (njemačka modna firma i Semijev sponzor). ${ }^{66}$ Ruska tenisačica Marija Šarapova planirala je privremeno promijeniti prezime u Sugarpova, kako bi promovirala svoju kompaniju za proizvodnju slatkiša i u tom smislu zahtjev je podnijela Vrhovnom sudu u Floridi. ${ }^{67}$

2.3. Nadimak je opisno ime koje se daje uz ili umjesto službenog imena ili naziva koji se koristi za nekog pojedinca, a najčešće predstavlja kratak, smiješan, pogrdan, zamjenski ili nekakav drugi oblik imena neke osobe. Nadimak se upotrebljava uz pravo ime, ili umjesto njega, a nadijevaju ga drugi. Neki nadimci, često i pejorativni, mogu postati i prezimena, a često su podrugljivi ili izražavaju neku osobitu originalnost nositelja. ${ }^{68}$ Nadimci se osobito često nadijevaju po tjelesnim ili kakvim drugim nedostacima. Nadimcima su slični i pseudonimi, s tim što su oni obično druga ili zamjenska imena poznatih osoba. Pseudonimi se od nadimaka razlikuju, među ostalim, i po tome što ih, u pravilu, kao stalna zamjenska ili kao prigodna imena, biraju same te osobe, a ne netko drugi. ${ }^{69}$

Metaforično izražavanje kojim se postiže učinkovitost sadržaja i primateljima prenosi borbena, natjecateljska dinamika dominantno je u sportskim iskazima. U jeziku medija najčešće se umjesto navođenja imena sportaša, na njega upućuje isticanjem osobine, dijela tijela, rekvizita i sl. po kojima je postao poznat i prepoznatljiv. Tako je boksač Željko Mavrović postao Šaka sa Srednjaka, tenisač Goran Ivanišević tijekom svoje karijere u medijima spominjan je kao Naš Najbolji Reket. Tako su nadimci kao svojevrsne metafore uobičajeni u tekstovima sportske tematike, a najčešće se njima ističu snaga i borbenost igrača: Vatreni su metafora za hrvatsku nogometnu reprezentaciju, Kauboji su nadimak hrvatske rukometne reprezentacije jer je na terenu borbeno kao na Divljemu zapadu, Vukovi su metafora za KK Cibona. Neki su nadimci spoj metafore i metonimije, npr. naša najbolja skijašica Janica Kostelić u medijima je dobila nadimak Snježna Kraljica. ${ }^{70}$

Što zbog svojih sklonosti, što zbog obožavanja navijača i novinara, mnogi su veliki sportaši dobili nadimak po kojem su čak bili poznatiji nego po vlastitom

66 Tako MATIĆ, S., Zbog Olimpijade se odrekao i imena, podatak na stranici: http://www.dw.com/ hr/zbog-olimpijade-se-odrekao-i-imena/a-17429094., (22. XII. 2017.).

${ }_{67}$ Podatak na stranici: http://m.sportske.net/vest/tenis/slatka-k-o-secer-sarapova-postaje-sugarpova -141870.html. (22. XII. 2017.). 2017.).

68 Vidi Proleksis enciklopedija online, podatak na stranici: http://proleksis.lzmk.hr/6411/. (22. XII.

${ }^{69}$ Usp. Hrvatska enciklopedija, LZ „Miroslav Krleža“, Zagreb, 1999.-2009.

70 Vidi BARTOLEC, G. B., „Vatreni, Kauboji i Stara dama (metafora i metonimija u medijima)“, Hrvatski jezik, 2015., broj 1, str. 6-9. 
imenu i prezimenu. Športske vještine i znanje, izgled, karakter, frizure, tetovaže, događaj i navike iz djetinstva ili ponašanje izvan terena, način života, vodeće su odrednice koje su utjecale na ovakvo obilježavanje sportaša. Sportaši su sve više prepoznatljivi po nadimcima (nickname) koje su im najčešće nadjenuli navijači (ekipe za koju igraju ili protivničke ekipe koji im daju, u pravilu, uvredljive ili posprdne nadimke) ${ }^{71}$ primjerice zbog lakšeg skandiranja njihova imena, a u skladu s njihovim ponašanjem na terenu (Animal, Doctor, Butcher, Braveheart, The Snarling Dog, Vatreni Lakat), značajem za ekipu (Brain, Boss), kvalitetom (King James, Magic Johnson, The Special One, Il Fenomeno, Dino Nacionale), izgledom (Der Kaiser, El Flaco - The Skinny One) i sl. Značajan dio nadimaka nastao je iz raznih varijacija njihova imena ili prezimena (Beckham-Becks, Zajec-Zeko, Šurjak-Šure, Kićanović-Kića, Željko-Žele, Krešimir-Krešo) ili su to nadimci koje nose još iz djetinstva (Baka, Prajo). Navijači kad igračima daju nadimak zapravo se s njima intimiziraju, čine ih dijelom svojega svijeta i pristaju na njihovu blizinu. ${ }^{72}$

Razvidno je da zaštita nadimka (športaša), bez obzira na njegovu čestu uporabu u svrhu identifikacije i individualizacije športaša i ljudi uopće, nije izrijekom uređen hrvatskim propisima. Nadimak je ime, koje nije službeno, a koje se daje od strane prijatelja ili neprijatelja. Nadimak ima puni učinak kada postane stalan, odnosno konvencionalan, pa ga je i vrlo teško odstraniti, kao što je slučaj i s tetovažom. ${ }^{73}$ Iako Zakon o osobnom imenu (Narodne novine, broj 118/12, 70/17.) u čl. 2. st. 1. izrijekom određuje da se osobno ime sastoji od imena i prezimena te time ne uključuje izrijekom u sferu zaštite i nadimak neke osobe, držimo da bi i on kao sastavni dio imidža sportaša trebao uživati zaštitu prema propisima kojima se uređuje pravo osobnosti, jer je nesumnjivo oznaka koja služi identifikaciji i individualizaciji sportaša, koja ga razlikuje od drugih osoba i koji se kao takav često neovlašteno koristi u komercijalne svrhe. Spomenuli bismo samo neke od poznatijih nadimaka sportaša: Stjepan Bobek-Štef, Mirza Delibašić-Kindže, Željko Stinčić-Stina, Robert

71 „Navijači, simpatizeri, drukeri, slučajni prolaznici, promatrači (zovite ih kako god hoćete) nogometnih, košarkaških, odbojkaških, rukometnih i inih sastava, odvajkada su nerazdvojna "koreografija" svakoga sportskog kolektiva na svijetu. Zbog njih se mijenjaju pravila i donose statuti; u ponekim slučajevima mogu (direktno ili indirektno) utjecati čak i na transfere igrača, smjenjuju uprave, "skidaju glave". No, nemali broj puta u igranim filmovima "najdražih" glavni su majstori procesa prišivanja nadimaka svojim ljubimcima, a vlastoručnim kreacijama često oduševljavaju (ili pak zbunjuju) mnoge ljubitelje "smijeha i rekreacije". PAVLIĆ, A., Imena luda stvaraju se svuda, http://www.hrsport.net/ mobile/blogovi/421911/vremeplov/imena-luda-stvaraju-se-svuda/. (22. XII. 2017.).

72 Vidi Čemu služe nadimci?, podatak na stranici: https://books.google.hr/books?id=kGwtDwAAQ BAJ\&pg=PT138\&lpg=PT138\&dq=nadimak\&source=bl\&ots=J9loBT5sSZ\&sig=Pn- o0vpD99918mO06 H1MxTYJSP4\&hl=hr\&sa=X\&ved=0ahUKEwih8M7EzvfXAhXIa1AKHaxMDaQ4HhDoAQglMAA\#v $=$ onepage $\& \mathrm{q}=$ nadimak $\& \mathrm{f}=$ false. (22. XII. 2017.).

73 Vidi http://bs.wikipedia.org/wiki/Nadimak. (22. XII. 2017.). 
Prosinečki-Žuti, Safet Sušić-Pape, Asim Ferhatović-Hase, Blaž Slišković-Baka, Toni Kukoč-Pink Panter, Goran Ivanišević-Zec, Aleksandar Petrović-Aco. ${ }^{74}$

Nadimak je posebno učestao i zastupljen kod sportskih klubova. Geneza mnogih nadimaka proizašla je iz klupskih boja i šara dresova, simbola na grbu i(li) maskote, životinja koje simboliziraju određeni klub, a ponešto intrigantniji nastali su iz imena ili djelatnosti sponzora, načina igre ili pak povijesnog značenja, odnosno nastanka. ${ }^{75}$ Primjerice, Everton-Toffees (Karamele, Mliječni Keksi); Chievo Mussi Volanti (Leteći Magarci); Sunderland - Black Cats (Crne Mačke); Juventus - Vecchia Signora (Stara Dama); Valencia - Los Murciélagos (Šišmiši); Arsenal - The Gunners (Topnici), West Ham United - The Hammers (Ćekićari); Hajduk - Majstor s Mora, Bili; Jugoplastika - Žuti; Chelsea - Pensioners (Penzioneri); Liverpool - Reds (Crveni); Leicster City - Foxes (Lisice); Manchester City Citizens (Građani); Manchester United - Red Devils (Crveni Vragovi), ManU.; Velež - Rođeni; Zrinjski - Plemići; Olimpija - Zmajčeki itd.

Imena sportskih klubova iz SAD-a sastoje se iz dva dijela. Prvi dio je ime grada ili države iz koje klub dolazi, a drugi dio imena (nadimak) naknadno se određuje na javnim natječajima, na natjecanjima na kojima su glasali navijači, na temelju odluke vlasnika, u skladu s povijesti i tradicijom područja iz kojeg dolaze i sl. Primjerice, Los Angeles - Lakers (Jezerčani); Golden State - Warriors (Ratnici); Sacramento - Kings (Kraljevi); San Antonio - Spurs (Mamuze); Houston - Rockets (Rakete); Utah - Jazz (Džezeri); Pittsburg - Pirates (Pirati); Dallas - Cowboys (Kauboji); Washington - Red Skins (Crvenokošci); Boston - Celtics (Sveci), Red Sox (Crvene Čarape); New York - Aankees (Jenkiji) itd.

74 Air Jordan, Magic Johnson, Wayne The Great One Gretzky, Babe Ruth, samo su neki od najboljih sportaša u američkoj povijesti čija se imena vječno vežu uz njihove nadimke. I današnji najpoznatiji akteri američkog sporta često imaju živopisne nadimke po kojima će ih se pamtiti. Primjerice, Matt Ryan - Matty Ice (Ledeni Matty), igrač američkog nogometa, nadimak je zaslužio nakon reklamiranja pivskog brenda naziva Natty Ice, ali također i zbog hladne glave te čvrstih i ledenih živaca. LeBron James - King James (Kralj James), košarkaš, Sidney Crosby - The Next One (Sljedeći), hokejaš, nadimak koji je naslijedio od Erica Lindrosa daje jasnu aluziju da se radi o svojevrsnom nasljedniku Waynea Gretzkog, poznatog i kao The Great One. Maurice Jones-Drew - Mojo (Amajlija), igrač američkog nogometa, simpatičnom igrom riječi, spajanjem imena i prezima, dobio se nadimak koji u malo slobodnijem prijevodu znači sretna amajlija. Calvin Johnson, Megatron (zli lik iz filma 'Transformeri'), igrač američkog nogometa, nadimak koji je dobio od bivšeg klupskog kolege Roya Williamsa najbolje oslikava fizičke kvalitete ovog novopečenog Pro Bowlera. Megatron uništava protivničke obrane svojim fizičkim prisustvom, kada se zbog visine, snage i skočnosti izdiže do lopte. Roy Halladay - Doc (Doktor), igrač bejzbola, zbog sličnosti prezimena s legendom Divljeg zapada Docom Hollidayem, Paul Pierce - The Truth (Istina), košarkaš, nakon jedne od utakmice Lakersa i Celticsa, Shaquille O'Neal je za bostonske novine rekao da je Pierce prava istina od igrača. Albert Pujols - The Machine (Stroj), igrač bejzbola, u karijeri je svake sezone imao fantastične statistike, pa je na taj je način zaradio nadimak Stroj, jer je teško vjerovati kako je obično ljudsko biće sposobno pružati toliko konstantno dobre partije u periodu od deset godina. James Harrison Silverback, Deebo (Srebrni gorila, Deebo - zli lik iz filma 'Friday'), igrač američkog nogometa, jak je, brz i agresivan kao veliki gorila, a u isto vrijeme podmukao kao Deebo. Tim Lincecum - The Freak (Cudak, Nakaza), igrač bejzbola, svojim izgledom mogao bi se uklopiti u obitelj Adams, ali način kojim baca loptu naprosto je nevjerojatan. IVKOVIĆ, I., Top 10 nadimaka vrhunskih američkih sportaša, Podatak na stranici: http://www.tportal.hr/sport/magazin/138049/Top-10-nadimaka-vrhunskih-americkih-sportasa. html. (22. XII. 2017.)

75 Tako PAVLIĆ, A., Imena luda stvaraju se svuda, http://www.hrsport.net/mobile/blogovi/421911/ vremeplov/imena-luda-stvaraju-se-svuda/. (22. XII. 2017.). 
Osim službenih imena, navijači, kao i novinari, često svojim reprezentacijama dodaju i neke nazive od milja. Kriteriji po kojima se odlučuju za nadimke su najčešće boja dresova, maskote, neki događaji koji su obilježili klupsku povijest ili ekipna osobnost. Spomenuli bismo, primjerice, Brazil: "Selecao" (Izabrani, Nacionalni Tim); Nizozemska: "Oranje" (Narančasti); Španjolska: "La Furia Roja" (Crvena Furija); Engleska: "The Three Lions" (Tri Lava, često i Gordi Albion); Argentina - "La Albiceleste" ili "Los Gauchos" (Nebeskoplavobijeli, Gaučosi); Bosna i Hercegovina: "Zmajevi"; SAD: "The Yanks" ili “Stars \& Stripes" (Jenkiji, Zvijezde i Pruge); Rusija: "Sbornaya” (Nacionalni Tim); Njemačka: „Elf“"(Nacionalni Tim); Hrvatska: „Vatreni“, „Kauboji“ itd.

2.4. U novije vrijeme prepoznatljiv dio imidža športaša razni su oblici i boje frizura. Frizura (njem. Frisur, franc. frisure, prema franc. friser: kovrčati < lat. frigere: pržiti), jest način na koji se uređuje (češlja, reže i plete) kosa ${ }^{76}$ Frizura se dobiva oblikovanjem kose. Postoje mnogi načini izrade frizura od jednostavnog rezanja škarama do složenih umjetničkih frizura raznih boja i oblika. Oblikovanje frizure može uključivati rezanje kose, bojanje, dodavanje ekstenzija, kovrčanje, izradu trajne itd. Frizurom se može izraziti stav poput suprotstavljanja društvenim konvencionalnim normama (punk frizura, irokeza), naglasiti pripadnost supkulturi (nulerica kod skinheadsa) ili vjerskoj zajednici (redovničke frizure). ${ }^{77}$

Kako bi na terenu izgledali što atraktivnije, brojne sportske zvijezde pripremile su posebne frizure. Promjene frizura također utječu na formiranje imidža tj. slike koju sportaši ostavljaju na okolinu. ${ }^{78}$

Prvi svjetski trend koji su iznjedrili nogometaši nastao je sredinom osamdesetih, $\mathrm{u}$ vidu do tada neviđene frizure. Nijemci su tu frizuru nazivali Vokuhila od skraćenih riječi vorne-kurz - hinten-lang (naprijed kratko - natrag dugo). Englezi su prvu globalnu nogometašku frizuru nazvali Mullet, dok je na našim područjima ova frizura nazvana 'fudbalerka'. Glavni predstavnici ove frizure bili su velikani tadašnje Zapadne Njemačke Rudi Voller i Oliver Kahn. ${ }^{79}$ Od milja naziva se još i fuca, fulja, fus, fulijana. Neko vrijeme nosili su ih i nogometni reprezentativci Njemačke, pa se nazivala još i 'bundeska'. Fudbalerka je spoj kratke i duge kose. Odnosno, kosa je kratko ošišana na prednjem, a puštena da raste na stražnjem dijelu glave. ${ }^{80}$

Među nogometašima bila je poznata i frizura nazvana po zemlji podrijetla 'talijanka'. Predvodnici trenda bili su talijanski nogometaši Paolo Maldini i Francesco Totti. Ovu frizuru krasio je razdjeljak na sredini glave, a bilo je važno

76 Vidi „Frizura“, Hrvatska enciklopedija, LZ „Miroslav Krleža, Zagreb, 1999.-2009.

77 Tako Frizura, podatak na stranici: https://hr.wikipedia.org/wiki/Frizura. (22. XII. 2017.).

78 Vidi BARTOLUCI, S. - TOMIĆ, D., Više od riječi - neverbalna komunikacija trenera i sportaša (1. dio), str. 8-9. Podatak na stranici: http://ukth.hr/media/files/4-10-bartoluci-2-2013.pdf. (22. XII. 2017.).

79 Usp. BOŽIĆ, I., 'Fudbalerke' $i$ druge frizure nogometaša, podatak na stranici: https://www. srednja.hr/zabava/moda/fudbalerke-i-druge-frizure-nogometasa/. (22. XII. 2017.).

80 Tako VRANEŠIĆ, V., Povratak najgore frizure svih vremena: Fudbalerka uzvraća udarac, podatak na stranici: http://net.hr/zena/moda/povratak-najgore-frizure-svih-vremena-fudbalerka-uzvracaudarac/. (22. XII. 2017.). 
i da je slijepljena s velikim količinama gela. Hrvatski predstavnici ove frizure bili su, primjerice, Dario Šimić te Silvio Marić. Možemo kazati da danas nema više jedinstvenog trenda među nogometašima. Irokeze, afro-frizure, pletenice, moderne nestašne frizure, sve su prisutne na sportskim terenima ${ }^{81}$ Tako su po ,irokez" frizuri bili poznati i prepoznatljivi: Mario Balotelli, Željko Mavrović, Marek Hamsik i drugi. Tzv. ,afro-frizure“" promovirali su i po njima su bili prepoznatljivi Carlos Valderama, Rio Ferdinand, Benoit Assou-Ekotto, Marouane Fellaini, Raheem Sterling, Ruud Gulit i drugi. Po ,pletenicama“ ili kovrčavoj kosi su, primjerice, bili poznati Abel Xavier i Taribo West, Bacary Sagna, Frank Rykard. Po „repiću“ su među najpoznatijim sportašima svakako Zlatan Ibrahimović, Gareth Bale, Roberto Baggio, Ronaldinho, Domagoj Vida, Dado Pršo, Giovanni Simeone. Ipak, pojedinci nemaju baš nikakve mjere kada je u pitanju izgled njihove glave i frizure. ${ }^{82}$ U najmanju ruku ekstravagandne frizure nosili su ili nose Manuel Cange Loco, Layvin Kurzawa, Djibril Cisse, Rigobert Song, Dominic Oduro, Marko Livaja, Bastien Hery i drugi.

Treba kazati da su neki sportaši zbog svoje frizure imali i probleme. Tako se Mario Balotelli, koji se volio isticati sa svojim ponekad smiješnim frizurama, prilikom dolaska u AC Milan, morao odreći među ostalim i ekstravagantnih frizura. To je inače klauzula bazirana na onoj koju potpisuju vojni piloti talijanskog ratnog zrakoplovstva. ${ }^{83}$ Pierre Emerick Aubameyang (Borussia Dortmund) izazvao je kontroverze u klubu, jer njegova nova frizura nije bila po ukusu čelnika Milijunera, a razlog je marketinške prirode. Naime, Aubameyang je na jednoj utakmici namjerno promovirao svog sponzora, kompaniju Nike, tako što je na glavi iscrtao ružičasti znak ove tvrtke, a Puma ne samo što pravi dresove već ima i udio u vlasništvu kluba Borussia što je izazvalo ozbiljan problem..$^{84} \mathrm{U}$ finalu ženskog skoka u dalj Bjeloruskinja Anastasja Mirončik-Ivanova osvojila je četvrto mjesto. No, detaljna analiza otkrila je kako je mogla uzeti zlato, samo da nije imala frizuru koju je imala. Ova je 22-godišnjakinja nastupila s kosom svezanom u rep, a on je ostavio trag u pijesku na 6,74. Ali njezino je tijelo ostavilo trag 15 -ak cm dalje, što bi joj donijelo zlato. ${ }^{85}$

Iako su zbog popularnosti, raširenosti i komercijalnog te medijskog praćenja nogometa frizure nogometaša u prvom planu, a posebno one ekstravagantne i smiješne, sportaši iz drugih sportova prepoznatljivi su i ističu se svojim frizurama

81 Vidi BOŽIĆ, I., 'Fudbalerke' i druge frizure nogometaša, podatak na stranici: https://www.srednja. hr/zabava/moda/fudbalerke-i-druge-frizure-nogometasa/. (22. XII. 2017.).

82 Vidi:http://sportski-noviteti.com/nogomet/ovo-su-najgore-frizure-koje-su-videne-na-nogometnim -terenima/; VUKASINOVIĆ, A., Najgore frizure u povijesti SP-a: Ronaldo i 'ludi' West, podatak na stranici; https://www.24sata.hr/sport/najgore-frizure-u-povijesti-sp-a-ronaldo-i-ludi-west-175640 - 24 sata.hr.; Martyn Thomas, 6 najgorih "frizura" u povijesti sporta, podatak na stranici: http://www.redbull. $\mathrm{hr} / \mathrm{cs} /$ Satellite/hr_HR/Article/6-najgorih-frizura-u-povijesti-sporta-021242921459721. (22. XII. 2017.).

83 Podatak na stranici: http://www.gosucker.com/1/Hrvatska/0/2/Sport/26/Sportske-novosti/Kolikoce-izdrzati-Balotelliju-zabranili-cigarete,-alkohol,-izlaske-i-lude-frizure-442170.html. (22. XII. 2017.).

84 Vidi Aubameyang u problemima zbog frizure, podatak na stranici: http://ba.n1info.com/a141333/ Sport-Klub/Nogomet/Aubameyang-u-problemima-zbog-frizure.html. (22. XII. 2017.).

85 Usp. Bizarna situacija ili teška greška atletičarke, Ostala bez zlata zbog frizure, Source.ba Sport, 3. IX. 2011., http://www.source.ba/clanak/882481162368/. (22. XII. 2017.). 
(Kevin Pietersen - kriket, Jaromir Jagr - hokej, Dennis Rodman - košarka, Elfrid Payton - košarka, Peter Wright - igrač pikada, Cedric Sorhaindo - rukomet i dr.).

Kao negacija frizure, dolazi kod muške populacije i do trenda brijanja glave. Poznati ,ćelavci“", odnosno izbrijane glave među sportašima bili su ili jesu Michael Jordan, Zinedine Zidane, Roberto Carlos, Arjen Robben, Pierluigi Collina.

Legendarni engleski nogometaš Bobby Charlton bio je prepoznatljiv sa svojom frizurom tzv. "preklapačom" jer je volio preostalu kosu prebaciti preko ćelave glave ${ }^{86}$ Sličnu frizuru imao je i nogometaš „Crvene zvezde“ Dragan Džajić.

$\mathrm{U}$ radu nismo posebno isticali frizure poznatih sportašica jer, po prirodi stvari, sportašice drže do urednosti svojih frizura i često ih mijenjaju pa se teško može kazati da su prepoznatljive po jednoj te istoj frizuri u duljem vremenskom razdoblju. Spomenuli bismo samo kao interesantne i nesvakidašnje frizure koje su kreirale Emma Green, Alyson Felix, Funmi Jimoh, Ariane Friedrich, Blanka Vlašić i Sandra Perković.

Iako u svijetu sporta u posljednjih desetak godina uglavnom dominiraju frizure ili tetovaže kao modni detalj, nekada su brkovi bili šmekerski detalj koji je odvajao „prave face“ od onih „ostalih“" ${ }^{87}$ Primjerice, po brkovima kao zaštitnom znaku svojega imidža posebno su se isticali Rollie Fingers, igrač baseballa, nogometaš Roberto Rivelino, plivač Mark Spitz, kečer Hulk Hogan i dr.

Brojni sportaši prepoznatljivi su i po bradi, a nerijetko i po bradi i brkovima. Primjerice, igrač američkog nogometa Breitt Keisel, borac UFC-a Connor Mc Gregor, košarkaš James Harden, nogometaši Tim Howard, Slaven Bilić, Baka Slišković, rukometaši Nikola Karabatić i Ivano Balić i dr.

2.5. Treba napomenuti da je prepoznatljivi dio imidža nekih sportaša i njihovo ponašanje (način koncentracije, ulaska na sportski teren, komunikacija s navijačima i sl.), odnosno pokreti prilikom proslavljanja pogotka ili pobjede (ples, premetanje/ salto i sl.).

Čeh Antonjin Panenka nije ni sanjao da će njegov kazneni udarac postati tako popularan u modernom nogometu. Zahvaljujući odlučujućem kaznenom udarcu (penalu) u finalu protiv Zapadne Njemačke, Čehoslovačka postaje prvak Europe. Tada se protivnički vratar bacio na lijevu stranu dok je Panenka lagano potkopao loptu. Od tada u nogometnoj terminologiji postoji i naziv "Panenka penal". Ovaj kazneni udarac promijenio je povijest nogometa, a tijekom svih ovih godina puno nogometaša pokušalo je imitirati Panenku. ${ }^{88}$

Nogometna povijest pamti neke zaista otkačene proslave pogodaka. Na primjer, Robbie Fowler je ušmrkavao gol-aut liniju praveći se da je kokain, a Paolo di Canio fašistički je salutirao navijačima Lazija u derbiju protiv Rome. Temuri Ketsbaia je

\footnotetext{
${ }^{86}$ Podatak na stranici: http://www.index.hr/black/clanak/beckhamova-frizura-najzapazenija-usvijetu-sportasa/194281.aspx.

87 Vidi $\breve{C}$ uveni brkovi svetskog sporta, podatak na stranici http://hotsport.rs/2012/11/04/cuvenibrkovi-svetskog-sporta/ (18. XII. 2017.).

88 Vidi Antonjin Panenka - Penal koji je promenio fudbal, http://sportskasecanja.com/antonjinpanenka-penal-koji-je-promenio-fudbal/. (22. XII. 2017.).
} 
ostavio trag u Premiershipu skidanjem dresa te šutiranjem reklama pokraj terena, a Robbie Keane ostao je poznat po svom prednjem kolutu te imaginarnom strojnicom kojom bi pucao po navijačima. ${ }^{89}$ Suarez je tri puta do sada uhvaćen kako grize suparnike. Dok je još igrao u Ajaxu ugrizao je igrača PSV-a Otmana Bakkala za vrat poput pravog vampira. U Engleskoj je nastradao branič Cheseaja Branislav Ivanović, a najčuveniji se ugriz dogodio na Svjetskom prvenstvu kada je pred očima cijelog svijeta zagrizao u rame Giorgia Chiellinija. ${ }^{90}$

Uvriježeno je mišljenje da su sportaši neskloni porocimai “iščašenom" ponašanju. Međutim, napose u vrhunskom sportu sve češće smo svjedoci "iskakanja" brojnih sportaša koji jednostavno teško podnose visoke sportske kriterije, silnu odgovornost i stres i olako se odaju porocima koji ih uništavaju i praktički spaljuju veliki novac koji su mukotrpno zarađivali. Uistinu, dio sportaša, pa čak i onih najvećih i najuspješnijih, zapnu u porok - neki prokockaju imetak, neki ga potroše na droge, a neki na alkohol. ${ }^{91}$

Visaš Uhov je pijan zaspao na strunjači poslije skoka na mitingu, Ivan Uhov, skakač u vis, možda je i najpoznatiji pijanac na terenu. Kobna je bila kombinacija votke i Red Bulla uoči mitinga u Lausannei. ${ }^{92}$ Sjajni čileanski veznjak Arturo Vidal doživio je prometnu nesreću sa svojom suprugom, vozivši svoj skupocjeni Ferrari u pijanom stanju. Paul Gascoigne, sjajni engleski nogometaš, i tijekom karijere i kasnije bio je znan kao mahnit pijanac. Uz nezaobilazne tučnjave po barovima, prometne nesreće, vrijeđanja svih oko sebe. George Best se nikad nije smirivao s alkoholom. K tome, bio je magnet za afere koje je sam na sebe privlačio zbog stalnog opijanja. Ništa ga nije moglo spriječiti u alkoholiziranju, pa je i nakon transplantacije jetre nastavio piti. Charles Barkley bio je fenomenalan košarkaš, no bio je i velika pijandura. Čuveni brazilski nogometaš Ronaldinho, skupa sa svojim prijateljem Adrianom, također vrhunskim nogometašem, imao je isto problema s čašicom previše. Izbornik rukometne reprezentacije Francuske Claude Onesta i kapetan Nikola Karabatić u teškom alkoholiziranom stanju su u studiju čuvenog francuskog dnevnika L'Equipe, slomili novinarski stol. Potom su pred uključenim kamerama Karabatić i Barachet uhvatili novinara s kojim su razgovarali i nasilno ga razodjenuli.93

Privatni život sportaša obilježen je i preljubima, pa se tako u medijima pratilo „ljubavne aktivnosti“ Tigera Woodsa, Jessea Jamesa, Ashleyja Colea, Johna Terryja, Ryana Giggsa koji je varao suprugu s bratovom ženom, a sportska veličina i imidž

89 Podatak na stranici: http://sportske.jutarnji.hr/pogledajte-skandaloznu-proslavu-gola-zbog-kojeje-cavani-izletio-iz-igre-/1229031/. (22. XII. 2017.).

90 Suarez ponovo na djelu, da li je ovo pokusaj ugriza? Pogledajte video i presudite sami.

February 25th, 2015 | by admin. Podatak na stranici: http://sportski-noviteti.com/nogomet/ovo-sunajgore-frizure-koje-su-videne-na-nogometnim-terenima/. (22. XII. 2017.).

91 Vidi KAČIĆ KARLIN, A., Kad sportaš loče, skandal je zajamčen!, 7Dnevno, 13. II. 2015., http:// www.dnevno.hr/sport/kad-sportas-loce-skandal-je-zajamcen-144904. (22. XII. 2017.).

92 Tako PAUN, V., To ti je neki sportski život: Čašica nam je svima u krvi, 24sata, 24. V. 2010., http:// www.24sata.hr/sport/to-ti-je-neki-sportski-zivot-casica-nam-je-svima-u-krvi-171444. (22. XII. 2017.).

93 Usp. KAČIĆ KARLIN, A., Kad sportaš loče, skandal je zajamčen!, 7Dnevno, 13. II. 2015., http:// www.dnevno.hr/sport/kad-sportas-loce-skandal-je-zajamcen-144904. (22. XII. 2017.). 
uzornog obiteljskog čovjeka činili su ga idealnim reklamnim modelom za sve što bi muškarci trebali željeti i smatrali su ga jednom od posljednjih zvijezda Premier Lige koja ima dobru reputaciju. I Tiger Woods ne samo da je bio iznimno dobar igrač golfa, nego je imao imidž simpatične, pristojne i umjerene osobe. Zbog toga je dobio unosne sponzorske ugovore od kozmetičke tvrtke Gillette, automobilske kompanije General Motors, koja je na njegovu imidžu gradila cijelu reklamnu kampanju za uspješni Buick Rendezvous, tvornice satova TAG Heuer, kompanije za proizvodnju bezalkoholnih pića Gatorade, „kartične“ tvrtke American Express, proizvođača sportske opreme Nike i desetaka drugih. No kada se skandal s njegovim preljubima počeo širiti, prva kompanija koja je suspendirala svoj sponzorski ugovor s njim bila je Gillette, a ubrzo nakon toga to je učinila Accenture, tvrtka koja se bavi savjetovanjem u sferi tehnologije. Potom je obznanio da više neće koristiti njegov lik u reklamnim kampanjama proizvođač satova TAG Heuer. ${ }^{94}$

Bilo je i sportaša koji su javno izjavili da mrze sport kojim se bave. "Igram tenis da preživim, iako ja tenis mrzim, mračnom i tajnom strašću, i uvijek sam ga mrzio", napisao je Andre Agassi u svojoj biografiji objavljenom 2009. U slučaju Agassija riječ je o pretjerano revnim roditeljima koji su ga od mladih dana gurali u tenis, a u njegovoj se karijeri nekad činilo da se više brine za svoj imidž i status slavne osobe, nego za tenis, iako je na kraju bio jedan od najboljih tenisača svog doba. ${ }^{95}$ Bilo je i drugih sportaša koji su bili poznati po negativnom ili pozitivnom utjecaju roditelja na njihovu karijeru. Spomenuli bismo tako primjere Janicu i Ivicu Kostelić, Blanku Vlašić, Mirjanu Lučić i dr.

Sudarima sklon Pastor Maldonado tvrdi da su za njegovu dugu karijeru u Formuli 1 i za njegovu reputaciju krivi novinari. Takvu reputaciju zaradio je nesmotrenim reakcijama, poput onih koje su dovele do tri kazne na Hungaroringu te kaznenih bodova nakon nje, izazivanjem sudara i čestim odlascima izvan staze. Iako je Pastor puno puta odustajao u posljednje dvije sezone, činjenica je da je dosta njih bilo uzrokovano tehničkim problemima s njegovim bolidom. ${ }^{96}$

Treba svakako napomenuti da se i u timskim sportovima poklanja sve veća pozornost imidžu, do te mjere da se unaprijed pripremaju i uvježbavaju svojevrsne predstave i rituali za pojedine situacije tijekom sportskog natjecanja, odnosno utakmice, od onih koje imaju za cilj pridonijeti većoj koncentriranosti i motiviranosti, pa do onih kojima se proslavljaju uspješni rezultati tijekom utakmice ili na kraju natjecanja (vlak ili gusjenica hrvatskih rukometaša, skakanje/bacanje $\mathrm{u}$ bazen trenera, bacanje u vodu kormilara u veslanju, motivacijski dogovor prije početka utakmice ili za vrijeme time-outa, ista boja kose i sl.).

94 Usp. MIHOVILOVIĆ, M., Veliki skandal najbogatijeg sportaša, Poslovni i sportski krah zbog seks afere, Nacional br. 736, 2009-12-22, http://arhiva.nacional.hr/clanak/74110/poslovni-i-sportskikrah-zbog-seks-afere. (22. XII. 2017.).

95 Vidi Sportaši koji su sport - mrzili, podatak na stranici: http://www.monitor.hr/vijesti/sportasikoji-su-sport-mrzili/301962/, (22. XII. 2017.).

96 Vidi MALDONADO: Zaslužujem dugu karijeru, a za imidž su krivi mediji, http://www. tvautomagazin.hr/maldonado-zasluzujem-dugu-karijeru-a-za-imidz-su-krivi-mediji/. (22. XII. 2017.). 
Imidž kluba percepcija je o njemu, njegovim sportskim uspjesima, kao i njegovo pozicioniranje u svijesti ljudi iz užeg i šireg okruženja. S aspekta marketinga, imidž sportske organizacije ili vrhunskog sportaša može biti transferiran ka nekoj profitnoj organizaciji koja želi bolju poziciju svojih proizvoda na tržištu. Isto tako, preko imidža sportske organizacije mogu se promovirati proizvodi profitne organizacije. Sportska marka je ime, simbol, dizajn ili njihova kombinacija koja se može putem licencijskog ugovora ustupiti profitnim organizacijama ili marketinškim agencijama. Profitne organizacije proizvode robu s aplikacijama sportske marke ili marke koriste u promotivne svrhe. Sportski događaj segment je potencijalnog sportskog proizvoda i ima velik broj zainteresiranih. To je prvenstveno publika koja prati sportski događaj, kao i masovni tzv. elektronski auditorij, ali i potencijalni oglašivači, kupci sportske marke itd. Imidž sportaša ili klubova/grupa potencijalni su sportski proizvodi koji se mogu transferirati u druge klubove ili marketinški koristiti kao ime ili lik. Oni mogu imati ulogu modela za ogled i u tom slučaju dobivaju širu socijalno-psihološku i kulturnu vrijednost. ${ }^{97}$

2.6. I dok je u prošlosti tetoviranje bilo znak raspoznavanja pojedinih društvenih skupina, a poslije oblik izražavanja pripadnosti pojedinim supkulturama poput nogometnih navijača, članova bandi ili pak pripadnosti kriminalnim organizacijama (primjerice, jakuze u Japanu), u moderno doba tetovaže su postale dio svakodnevnog života. ${ }^{98} \mathrm{U}$ novije su vrijeme prepoznatljivi dio imidža športaša i tetovaže na dijelovima tijela koji nisu prekriveni športskom opremom, iako su prepoznatljive i tetovaže koje su prekrivene sportskom opremom i koje se vide u trenutku kad sportaši zadignu dres kod proslave pogodaka), kod razmjene dresova nakon utakmice i sl. Uljepšavanje tijela tetovažama nije nova stvar, ali je očigledno u porastu, pa i kod sportaša.

Mnogi od njih vjeruju da im imena najbližih, brojevi, slike, simboli i crteži donose sreću, podsjećaju ih na važne momente u životima, ali sigurno ima i onih koji se na ovakav vid umjetnosti odlučuju da bi jednostavno privukli pozornost. Različiti su motivi, izgled i poruke pojedinih tetovaža - citati, imena i slike članova obitelji, najznačajniji datumi u životu, religijska obilježja, životinje, horoskopski znakovi, znakovi japanskog pisma, imena i znakovi sportskih klubova, seksualnih obilježja i poruka, povijesnih osoba, lokalpatriotskih motiva i dr. Kad smo već kod lokalpatriotskih motiva, recimo da je za vizualizacijom svetog Ante na tijelu 'posegnuo' boksač Ante Varnica, nekadašnji ragbijaški reprezentativac Ivica Nino Rubelj uljepšao je pak leđa rasterom Dioklecijanove palače, a po brojnim tetovažama ističu se i košarkaši Damir Markota i Mario Kasum.

Prvi igrači koji su započeli ovaj trend košarkaši su Dennis Rodman i Allen Iverson. Rodman je prije svega poznat po tetovažama i pirsingu i svakako se $u$ vrijeme kada je on nastupao u NBA-i nije mogao naći nitko sličan njemu. Jedan

97 Tako MARUŠIĆ, S., Upravljanje markom na primjeru nogometnog kluba Manchester United, Diplomski rad, Split, 2012., str. 9-10.

98 Vidi CAPAR, L., Ako danas želite biti originalni nemojte se tetovirati, Večernji list, 28. VIII. 2015., http://www.vecernji.hr/moda-i-ljepota/ako-danas-zelite-biti-originalni-nemojte-se-tetovirati-985324. (22. XII. 2017.). 
od najboljih igrača u povijesti ovog sporta, bek Miami Hita LeBron James nije odolio ovom trendu. Prema nekim podacima, ovaj tamnoputi igrač ima 31 tetovažu na svom tijelu. Igrač New York Knicksa JR Smith ima oko 70 tetovaža. Može se reći da u ostalim sportovima postoji umjerenost kada je riječ o tetoviranju. $\mathrm{Na}$ tijelima tenisača, rukometaša, odbojkaša, plivača može se naći tek po neku tetovažu. Po tetovažama su prepoznatljivi tenisač Janko Tipsarević, hrvatski vaterpolski reprezentativci Petar Muslim, Anđelo Šetka i Fran Paškvalin, a u rukometu još uvijek nitko nije uspio nadmašiti legendarnog Nijemca Štefana Krečmara po broju tetovaža. ${ }^{99}$

Ograničavanje tetoviranja na jednu-dvije sličice na tijelu iz današnje optike djeluje arhaično; srndać s loptom na nožnom listu Darija Srne ili, recimo, lik Popaja koji krasi tijelo nekadašnje nogometne nade Zvonimira Deranje infantilan je u odnosu na raskošne tetovaže Marija Mandžukića ili Vedrana Čorluke. Čini se da su među najvećim ljubiteljima tetovaža u svijetu sporta ipak nogometaši, pa možemo izdvojiti Zlatana Ibrahimovića s konglomeratom koječega na leđima, Dina Drpića, Ivana Rakitića, Davida Beckhama, Daniela Agera, Martina Škrtela, Danielea de Rossija. ${ }^{100}$ Tako je Zlatan Ibrahimović na utakmici s Caenom svoje ionako brojnim tetovažama ukrašeno tijelo, dodatno privremeno ukrasio sa 50 ispisanih imena (Carmen, Mariko, Antoine, Sawsan, Cheuy, Lida, Siatta, Rahma, Yaae, Abdullah i dr.), a sve kao sudionik kampanje protiv gladi World Food Programme. ${ }^{101}$ Od ispisivanja tetovaža po tijelu nisu imune ni sportašice. Tako je srbijanska natjecateljica u bodi-fitnesu Jelena Kasalović prepoznatljiva po vjerojatno najvećoj tetovaži u susjedstvu, a možda i šire. Tetovirala je zmaja gotovo preko cijeloga tijela, a ukupna duljina tetovaže je 1,5 metar. Izrada tetovaže trajala je više od pet mjeseci, a nakon tetoviranja je dobila nadimak "žena zmaj”. ${ }^{102}$

2.7. Odijevanje - Koliko se god sportašima i trenerima sportska odjeća činila prirodnom i udobnom, njihova prisutnost u javnosti zahtijeva da se načinom odijevanja, odabirom nakita, tjelesnih ukrasa, frizurom pošalje poruka poštovanja (sugovornika, publike, situacije), ozbiljnosti, profesionalnosti. Sportaši jednakom odjećom sugeriraju zajedništvo, koja na navijače, ali i na protivnike djeluje psihološki, naročito kada se radi o nastupima nacionalnih vrsta. Spomenuli bismo, primjerice, bijeli šal koji je nosio i po kojem je bio prepoznatljiv nogometni trener Miroslav Ćiro Blažević, odnosno bijelu kapu koju je nosio nogometni trener Igor

99 Vidi LUKIĆ, J., TETOVAŽE U SPORTU: simbol, poruka, ili..., SK-SPORTKLUB, 3. I. 2014., http://www.sportklub.rs/tetovaze-u-sportu-simbol-poruka-ili., (22. XII. 2017.).

100 Tako i Cristiano Ronaldo na svojem tijelu nema niti jednu tetovažu što je pomalo neobično s obzirom na trend među sportskim zvijezdama. „Nemam tetovaže jer često doniram krv“ kazao je Portugalac koji dvaput godišnje donira krv. LENKA GOSPODNETIĆ, Sportaši i manekeni u tatoo salonima: muškarci biraju navijačke motive, žene simbole s porukom, Slobodna Dalmacija, 24. 07. 2014., podatak na stranici: https://www.google.hr/?gfe_rd=cr\&ei=qP_fVY_yH4ve8gfuuI7YAg\#q=tetovaže+sp ortaši. (22. 12. 2017.).

101 Vidi Ibrahimović pokazao i objasnio svoje tetovaže, Sportsport.ba, 15. III. 2015., http://www.ibar. ba/ibrahimovic-pokazao-i-objasnio-svoje-tetovaze-video/. (22. XII. 2017.).

102 Tako ŠLJIVAK, M., Srbijanska sportiskinja je jedinstvena u svijetu sporta, 6. X. 2014., Pročitaj više na: http://sportsport.ba/magazin/srbijanska-sportiskinja-je-jedinstvena-u-svijetu-sporta/142249. (22. XII. 2017.). 
Pamić. Sportaši, kao svojevrsni ambasadori nacije, promiču nacionalne vizualne simbole, od kvadratića na dresovima, preko glagoljice ili hrvatskoga pletera na kravatama, nakitu ili nekom drugom predmetu, doprinose oblikovanju imidža nacije i jačaju postupak poistovjećivanja, važan za nacionalni sport općenito. ${ }^{103}$

U kakvim će se modnim kombinacijama sportaši prošetati na otvorenju Olimpijskih igara, u čemu će se boriti za odličja i što će nositi u olimpijskom selu, zaljubljenike u modu često zanima više od natjecanja. Otkako je 1936. donesena odluka o uvođenju olimpijske odore, sportskoj se odjeći posvećuje velika pozornost, pri čemu naravno najviše do mode drže države poput SAD-a, Francuske, Velike Britanije. ${ }^{104} \mathrm{U}$ All England Clubu pristali su privremeno odstupiti od kodeksa odijevanja tenisača i tenisačica u strogo bijelu boju tijekom olimpijskog teniskog turnira za vrijeme trajanja Igara u Londonu 2012. godine.

Dres je najvažniji dio uniforme sportaša. Bez obzira na to radi li se o klubu ili o reprezentaciji, svaki sportski dres jedinstven je na svoj način. Danas se dosta pažnje posvećuje lijepom dizajnu, kao i kvaliteti materijala, što omogućuje navijačima i sportašima nošenje dresa i izvan nogometnog terena. Dresovi s imenima poznatih nogometaša i mnogih drugih poznatih igrača koji su popularni kod navijača koji podržavaju ekipe za koje oni igraju, ali i njih osobno, donose još i veću prodaju. Dresovi Manchester Uniteda među najprodavanijima su u svijetu, a onaj s imenom Waynea Rooneya bio je na prvom mjestu liste najprodavanijih dresova engleskih klubova. ${ }^{105}$ Prateći modne trendove, sportski klubovi svoje standardne dresove izmijenili su novim detaljima poput nove boje ili retro izgleda brojeva na dresu, crta sa strane, izreza oko vrata. Tako je Hajduk prijavio novi službeni ,,maskirni““dres, a tzv. „kamuflažni dresovi“ nosili su prigodno i košarkaški timovi UNC i Michigan State na utakmici Veterans day na nosaču zrakoplova. Košarkaški klub Sacramento prezentirao je dresove za sezonu 2014./2015., a njihov izgled neodoljivo podsjeća na one koji su košarkaši te franšize nosili krajem prethodnog stoljeća. AC Milan i Manchester United predstavili su novi ,retro dres“ koji podsjeća na onaj iz uspješnih 80-tih godina.

Sportska obuća jedan je od najvažnijih dijelova sportske opreme svakog sportaša i nužna je za odvijanje sportskih aktivnosti. Najpoznatiji i najčešći oblik sportske obuće su tzv. tenisice koje već odavno nisu rezervirane samo za sportske

103 Usp. BARTOLUCI, S. - TOMIĆ, D., Više od riječi-neverbalna komunikacija trenera i sportaša (1. dio), str. 8-9., http://ukth.hr/media/files/4-10-bartoluci-2-2013.pdf. (22. XII. 2017.).

104 Primjerice, američki sportaši koji su svoju zemlju predstavljali na Olimpijskim igrama u Londonu, nosili su u službenim prigodama izvan sportskih borilišta, te u slobodno vrijeme odjeću koju je kreirao poznati dizajner Ralph Lauren. Međutim, odjeća je izazvala kontroverze u Sjedinjenim Američkim Državama kad se doznalo da je napravljena u Kini. Posebno je burno bilo u Kongresu gdje su bjesnili zbog odluke da se olimpijske uniforme nabave u Kini dok američka tekstilna industrija grca u problemima, a radnicima treba posao. Kongresnici su Američkom olimpijskom odboru poručili kako se treba sramiti zbog te odluke. „Kontroverze zbog opreme: Američka odjeća sašivena je u Kini“, Slobodna Dalmacija, 14. VII. 2012. http://www.slobodnadalmacija.hr/Mozaik/tabid/80/articleType/ArticleView/ articleId/180949/Default.aspx. (22. XII. 2017.).

105 Vidi MARUŠIĆ, S., Upravljanje markom na primjeru nogometnog kluba Manchester United, Diplomski rad, Split, 2012., str. 54. 
terene. Neke su od najpoznatijih marki tenisica: Chuck Taylor All-Stars, Converse All-Stars ili jednostavno „starke“ proizvode se od 1917. i danas su puno više od košarkaških tenisica što im je bila prvobitna namjena. Kao brand namijenjen onima koji su dovoljno nezavisni da ne slijede druge, ova mlada tvrtka udružila se s mladim sportom: košarkom. Te iste godine čovjek imenom Marquis Converse izradio je prve tenisice za košarku i nazvao ih Converse All-Stars. Godine 1923. igrač košarkaškog kluba Indiana Hoos ih je prihvatio, a one su dobile naziv Chuck Taylor All-Stars. Postale su najprodavanije tenisice za košarku ikad. Popularizirao ih je Charles Hollis "Chuck" Taylor i od 1923. zovu se po njemu. On je tako postao prvi sportaš koji je "zaštitio" neku modnu marku. ${ }^{106}$ Tenisice Air Jordan ili jednostavno Jordanice modna su marka sportske obuće i odjeće koju Nike dizajnira i proizvodi uz odobrenje bivšeg legendarnog košarkaša Michaela Jordana. Prvi model tenisica Air Jordan izdan je sada već davne 1985. i od tada godišnje se izdaje nekoliko modela što professional što casual tenisica za košarku. Prve tenisice Air Jordan I ili AJ I dizajnirao je Peter Moore za Michaela Jordana još 1984. godine, a iduće su ih godine mogli obuti i prvi kupci. Jordanice, u trenutku kada su izašle, nisu bile revolucionarne ni po čemu osim po jednom - boji. Košarkaškim parketima dotad je dominirala bijela boja, a Jordanice su dolazile u crveno-crnoj kombinaciji koja je današnjim košarkašima omogućila da nose tenisice kakve žele. ${ }^{107}$ Počeci priče o Air Jordan bili su povezani s mnogo buntovništva, NBA liga je, naime, Jordanu zabranila da ih nosi na igralištu jer crveno-crna kombinacija nije odgovarala unaprijed određenim bojama. Michael Jordan je unatoč tome na parket uvijek dotrčao u njima i svaki put dobio kaznu u visini od čak pet tisuća dolara. Tenisice su tako postale sinonimom buntovništva i odlučnosti, što je Nike vrijedno istaknuo i u svojim marketinškim aktivnostima. ${ }^{108}$ Upornost se isplatila jer se stvorila fama koja je ubrzo prerasla u kult. Adidas Stan Smith / Adidas Superstar - Model Stan Smith nastao je u 60-ima te bio namijenjen profesionalnim igračima tenisa, a danas je poznat po vrlo jednostavnom dizajnu koji ne sadrži čak ni prepoznatljive tri crte sa strane već tri reda sitnih rupica za protok zraka. Na prijelazu u 21. stoljeće model je ponovo izdan pod imenom Stan Smith II, a Stan Smith je postao najprodavaniji Adidasov model u povijesti. Najpoznatiji Pumin model potječe iz 1973., a u povijest ga je lansirao Tommie Smith koji je tijekom primanja medalje na Ljetnim olimpijskim igrama 1968. izveo pozdrav 'black power', a u tom je trenutku nosio upravo Suede. Stan Smith (ADIDAS) jedan je od modela tenisica koji je započeo uzdizanje sportske obuće do kultnog statusa. Ove tenisice pojavile su se 60-tih godina na teniskim terenima i ubrzo našle svoj put na ulice diljem svijeta, a posebne su po tome što su probile Adidas na američko tržište. Njihovu popularnost najbolje dokazuje i podatak da su jedne od najprodavanijih modela tenisica svih vremena.

106 Podatak na stranici: http://www.converse.hr/about/ (20. XII. 2017.).

107 Pročitajte više na: https://miss7.24sata.hr/moda/jordanice-kultni-model-tenisica-koji-radonosimo-4891 - miss7.24sata.hr (20. XII. 2017.).

108 Podatak na stranici: http://www.tenisice.hr/infoportal/kategorija/lifestyle/jordan-air.html (20. XII. 2017.). 
Dizajn ovih bijelih kožnih tenisica tada je postao klasik koji do danas nije izašao iz mode i koji je uveo Stana Smitha u pop-kulturu. ${ }^{109}$

Sastavni dio imidža nekih sportaša postala je upravo činjenica da nisu nosili športsku obuću (svakako u sportovima u kojima se ona uobičajeno nosi). Abebe Bikila, etiopijski vojnik, jedan je od sportaša koji je obilježio Olimpijske igre u Rimu 1960. godine jer je pobijedio u olimpijskom maratonu trčeći bosonog. Međutim, četiri godine poslije Abebe Bikila vratio se na Olimpijske igre u Tokio i opet osvojio zlatnu medalju. Ovaj put je nosio tenisice. ${ }^{110}$

2.8. Piercing, nakit i druga opasna oprema. Umjetnost ukrašavanja ljudskog tijela piercingom i tetovažom postala je toliko popularna u posljednjih nekoliko godina da je teško prošetati ulicom, otići u trgovački centar, crkvu ili gledati televiziju, a da ne vidite nekoga tko ima na sebi piercing ili tetovažu. Viđamo ih na nama bliskim osobama, prijateljima. Sama riječ piercing dolazi od engleskog glagola to pierce i znači probušiti ili probiti. Riječ je o tome da se buše određena mjesta ljudskog tijela, gdje se stvara otvor na kojem se može nositi nakit. Najčešće piercing se stavlja u uši, nos, jezik, usne, pupak, obrve, bradavice i genitalije. Za razliku od tetovaže, piercing nije trajne naravi, ali nosi veće rizike po zdravlje jer se radi o mehaničkom probijanju kože ili tkiva na mjestu koje se želi ukrasiti. Kao i tetovirane osobe, tako i osobe s piercingom žele privući pozornost na sebe, ${ }^{111}$ a to svakako vrijedi i za neke sportaše. Svaka osoba koja se bavi sportom (pa i rekreacijski) i nosi piercing ili nakit na vidljivom i izloženom mjestu, mora uzeti u obzir da time nastaje rizik od ozljede (za nju samu i druge osobe s kojima dolazi u kontakt tijekom sportskih aktivnosti. Službena pravila raznih sportova zabranjuju nošenje opreme koja može prouzročiti ozljedu igrača, koja je neprikladna za tu granu sporta, odnosno koja tom sportašu može dati neopravdanu prednost u odnosu na druge sportaše. Pravila igre određuju minimalnu opremu koja je potrebna za svakog igrača, te zabranjuju korištenje ičega što može biti opasno za ostale igrače ili samog igrača. Tako, primjerice, Službena pravila košarkaške igre, Svjetska košarkaška federacija (FIBA) od 29. travnja 2012., izrijekom propisuju da sva oprema koju koriste igrači kora biti prikladna za igru te da nije dopuštena oprema koja je napravljena tako da povećava visinu ili doseg igrača ili mu na bilo koji drugi način daje nepravednu prednost (Pravilo 4.4.1.). Posebno je propisano da igrači ne smiju nositi opremu (predmete) koji mogu prouzročiti ozljedu igrača (Pravilo 4.4.2.). U tom smislu sljedeći predmeti nisu dopušteni: štitnici za prst, ruku, ručni zglob, lakat ili podlakticu, vrpce ili steznici od kože, plastike, savitljive (mekane) plastike, metala ili bilo kojeg drugog tvrdog materijala, čak i ako imaju mekanu zaštitu; predmeti koji mogu posjeći ili prouzročiti ogrebotinu (nokti moraju biti

109 Pročitajte više na: https://miss7.24sata.hr/moda/tenisice-koje-su-osvojile-svijet-4828 miss7.24sata.hr. (22. XII. 2017.)

110 Usp. Jeste li znali da je olimpijski maraton u Rimu 1960. osvojio bosonogi etiopski vojnik, objavljeno na stranici: https://www.srednja.hr/sport/sport-sport/jeste-li-znali-da-je-olimpijski-maraton-urimu-1960-osvojio-bosonogi-etiopski-vojnik/ (21. XII. 2017.).

111 Tako Fra IVO PAVIĆ, Piercing - da ili ne, podatak na stranici: http://www.zupa-surkovac.com/ hr/article/20/piercing-da_ili_ne (20. XII. 2017.). 
kratko odrezani); pokrivala za glavu, ukrasi za kosu te nakit. I Međunarodna pravila rukometne igre, Hrvatski rukometni savez, Zagreb, 2010., propisuju u čl. 4.7. 4.9. kako sudac može zatražiti od igrača da skinu piercing i udaljiti ih iz igre dok to ne urade. Sudac treba od igrača zatražiti i da ukloni nakit, a nije dopušteno da igrač sudjeluje u igri ako bi flasterom prekrio nakit koji se smatra opasnim. Nije dopušteno nošenje i drugih predmeta koji mogu biti opasni po igrače. To uključuje, primjerice, štitnike za glavu, maske za lice, narukvice, satove, prstenje, vidljiv nakit na probušenim dijelovima tijela, ogrlice ili lančiće, naušnice, naočale bez vrpce za učvršćenje ili s tvrdim okvirom, kao i ostale predmete koji mogu biti opasni. $\mathrm{S}$ druge strane, moglo bi se zaključiti da igrači mogu nositi opremu koja se u toj sportskoj grani smatra neopasnom za samog igrača koji je nosi i za druge igrače. Tako, primjerice, različiti prsteni, malene naušnice i vidljiv nakit na probušenim dijelovima tijela mogu se dopustiti ako se prekriju ljepljivom vrpcom tako da više nisu opasni za suparničke igrače. Dopuštene su vrpce za kosu, rupci i kapetanske vrpce ako su načinjeni od mekanog i rastezljivog materijala. Ove pogodnosti koristili su i koriste neki sportaši, štoviše to je postao i sastavni dio njihova imidža. Veliki broj sportaša postao je prepoznatljiv po nošenju opreme i nakita u privatnom životu koji su inače nedopušteni za nošenje tijekom sportskih aktivnosti u grani sporta kojom se bave, a neki/e su postali i modeli za promoviranje takvih proizvoda (David Beckham, Antonija Mišura i dr.).

2.9. Promjena imidža. Imidž je potrebno stalno usavršavati, baš kao i ličnost/ osobnost. Kreacija imidža je dinamična aktivnost, što znači da je svakog trenutka podložan promjeni. Tu ne postoje pravila, nego sve ovisi o spremnosti sportaša na promjene u psihološkom, emotivnom i fizičkom smislu. Moguće su krupne promjene životnog stila koje podrazumijevaju, na primjer, promjenu kluba i lokacije stanovanja, kruga prijatelja i poznanika, u nekim slučajevima čak i promjenu tjelesne težine. Sve te promjene mogu izazvati stres i zahtijevaju odlučnost i strpljenje. ${ }^{12}$

Uspješna srpska atletičarka Ivana Španović šokirala je fanove na društvenoj mreži Instagram, kada je objavila fotografiju na kojoj ima poluobrijanu glavu i malo ju je teže prepoznati. ${ }^{113}$ Kako je za sportašice uobičajeno mijenjanje frizure, nakita ili stila odijevanja, veću pozornost obratit ćemo promjeni imidža kod sportaša. Zaštitni znak košarkaša Dennisa Rodmana bila je neobična frizura - na svakoj utakmici drukčija. Imidž su promijenili neki sportaši puštanjem brade, brkova ili dulje/ kraće kose (Zvonimir Boban, Aljoša Asanović, Slaven Bilić, Šime Vrsaljko, Lazar Marković). ${ }^{114}$ Najdrastičnije promjene imidža dogodile su se kad su neki sportaši promijenili spol. Bruce Jenner, osvajač olimpijske zlatne medalje u desetoboju u

112 Vidi MARJANOVIĆ, M., Strategije za izgradnju profesionalnog sportskog imidža, Savremenisport.com, 12. VII. 2014., http://savremenisport.com/teorija-sporta/sportski-marketing/9/260/ strategije-za-izgradnju-profesionalnog-sportskog-imidza. (22. XII. 2017.).

113 Tako i više kod: Mnogi su Ivanu Španović kritikovali zbog frizure, a usledio je odgovor koji će ih posramiti!, podatak na stranici: ttp://www.blic.rs/zabava/vesti/mnogi-su-ivanu-spanovic-kritikovalizbog-frizure-a-usledio-je-odgovor-koji-ce-ih/b5rr94p (21. XII. 2017.).

114 Vidi OBRENOVIĆ, A., Novi imidž Lazara Markovića, Sportske.Net, 20. VII. 2015., http://www. sportske.net/vest/dzet-set/novi-imidz-lazara-markovica-231575.html. (22. XII. 2017.). 
Montrealu 1976. i svjetski rekorder, koji je imao imidž macho muškarca, javno je priznao da se identificira kao žena i da mijenja spol, što je naposljetku i uradio (Caitlyn Jenner). ${ }^{115}$ Renée Richards, rođena 1934., američka je bivša profesionalna tenisačica. Godine 1975. Richardsova je imala operativni zahvat prilagodbe spola. Poznata je po tome što je 1976. godine Teniska asocijacija SAD-a odbila njezinu prijavu za sudjelovanje na turniru US Open navodeći kao razlog politiku organizatora turnira da jedino žene rođene kao žene mogu sudjelovati na turniru. Nakon što je tužila navedenu Asocijaciju, Vrhovni sud države New York je 1977. godine donio presudu u njezinu korist, što je bila ključna odluka za prava transseksualnih osoba. ${ }^{116}$ I čileanska tenisačica Andrea Paredes von Roth, rođena 1971. godine, operaciji prilagodbe spola podvrgnula se 2000 . godine. Ona je bila druga transseksualna osoba u povijesti tenisa kojoj je Međunarodna teniska organizacija nakon promjene spola dopustila nastup na profesionalnom teniskom turniru. ${ }^{117}$

\section{MERCHANDISING U SPORTU}

Potrebno je ukazati i na pojam „,merchandising”, koji ima neke sličnosti sa žigom. Pod tim pojmom podrazumijeva se sekundarno plasiranje na tržište izmišljenih likova, ali i stvarnih osoba, imena, naziva, zaštitnih obilježja nekog proizvoda, elemenata opreme, dizajna ili slika, i to izvan njihova stvarnog područja djelovanja i pojavljivanja s ciljem bolje prodaje robe i usluga. ${ }^{118} \mathrm{U}$ odnosu na znakove, pa tako i žigove i osobna imena, oni se ovdje ne rabe u njihovoj primarnoj, uobičajenoj funkciji označavanja izvora odnosno podrijetla proizvoda, nego se primjenjuju na druge produkte ili usluge i rabe se s obzirom na utjecaj što ga imaju kao poznati, odnosno čuveni (well-known) simboli. ${ }^{119}$ Specifičnost je merchandisinga to što se kod njega koristi tzv. emocionalno pozicioniranje proizvoda, tj. potrošačima se nastoji, pored osnovne svrhe proizvoda ili usluge, prenijeti dodatna ,psihološka svrha" proizvoda koja će potrošača dodatno povezati s proizvodom. Nastoji se postojeća simpatija, popularnost (fan club) prema nekom izmišljenom liku ili nekoj stvarnoj osobi (u našem slučaju športašu) prenijeti na proizvod. ${ }^{120}$ Stoga se i razlikuje character merchandising, kod kojeg se koriste izmišljene figure, likovi (npr. Asteriks, Garfield) i personality merchandising, kod kojeg se koriste imena, fotografije,

115 Tako kod Po prvi put kao žena Bruce će biti na naslovnici Vanity Faira, pročitajte više na: https:// www.24sata.hr/show/bruce-ce-se-prvi-put-kao-zena-pojaviti-naslovnici-vanity-faira-421654 - 24 sata.hr. (22. XII. 2017.).

116 Vidi Renee Richards still amazed she broke transgender taboo, podatak na stranici: https://www. reuters.com/article/us-usa-transgender-richards/renee-richards-still-amazed-she-broke-transgendertaboo-idUSKBNOMM18920150326. (22. XII. 2017.).

117 Tako Andrea je bila muškarac, a sad će igrati ženski tenis, pročitajte više na: https://www.24sata. $\mathrm{hr} /$ sport/andrea-je-bila-muskarac-a-sad-ce-igrati-zenski-tenis-113276 - 24sata.hr. (22. XII. 2017.).

118 Usp. JEREMIAH, Merchandising Intellectual Property Rights, Wiley \& Sons, Inc., 1997., str. 24.

119 Tako HART/FAZZANI, Intellectual Property Law, sec. edit., Palgrave, Hampshire \& N.Y., 2000., str. 123.

120 Vidi BAČIĆ, F. - PAVLOVIĆ, Š., Komentar Kaznenog zakona, Zagreb, 2004., str. 991. 
crteži, potpisi, glas i druge osobine osoba koje doista postoje ili su postojale (npr. David Beckham, Michael Jordan), a u javnosti nastupaju ili su nastupali pod svojim imenom. ${ }^{121}$ Merchandising je u biti ugovor kojim vlasnik određenog prava, najčešće žiga, ustupa to pravo na korištenje drugom poduzetniku sa svrhom stavljanja tog prava na proizvode koji su po svojoj prirodi znatno drugačiji od onih za koje je žig prethodno stvoren i registriran. ${ }^{122}$ Tako određeni proizvodi (majice, šalovi, šalice, kalendari, bedževi, školski pribor i sl.) mogu sadržavati sliku poznatih i popularnih sportaša, ali i razne lutke, maskote, igračke, privjesci za ključeve i sl., mogu biti kreirani u tri dimenzije po uzoru na lik poznatih sportaša, najčešće u animiranom ili karikaturalnom obliku.

\section{INDUSTRIJSKI DIZAJN I SPORT}

1. Pojam ,industrijski dizajn“123 upotrebljava se za označavanje rezultata i postupaka kreativno-umjetničkoga rada čija je svrha davanje ornamentalnoformalnoga izgleda i uobličenja proizvodima industrijske i masovne reprodukcije i uporabe. ${ }^{124}$ Prema zakonskoj definiciji, ,dizajn“ znači vanjski izgled proizvoda u cijelosti ili dijela proizvoda koji proizlazi iz njegovih obilježja, osobito crta, kontura (obrisa), boja, oblika, teksture i/ili materijala samoga proizvoda i/ili njegove ornamentacije. Proizvod pri tome znači bilo koji industrijski ili zanatski predmet uključujući, među ostalim, dijelove namijenjene uklapanju u složeni proizvod, pakiranje, opremu knjiga, grafičke simbole i tipografske oblike slova, ali isključujući računalne programe. Dizajnom se naziva vanjski izgled (pojavnost) nekoga proizvoda ili predmeta. Dizajn je ono što proizvod čini privlačnim, dopadljivim ili poželjnim, te na taj način bitno pridonosi prodaji proizvoda $\mathrm{i}$ povećanju njegove komercijalne vrijednosti. Industrijskim dizajnom kao jednim od oblika intelektualnoga vlasništva štite se prostorna ili plošna obilježja proizvoda (industrijski ili zanatski proizvedenog predmeta), vidljiva pri njegovoj normalnoj (namjenskoj) uporabi. Prostorna su obilježja oblik i obris proizvoda, a plošna su obilježja šare, crte, boje, tekstura te kombinacije navedenih obilježja. ${ }^{125}$

121 Detaljnije kod QUEST, „From Diana to Football - protection still found wanting (an update on personality character merchandising)“, Licensing executives society, New exchange, Issue 71: February - March 2000., str. 8.

122 Tako ŠUPERINA, M. - KOLAR-GREGORIĆ, T. - CVITANOVIĆ, L., „Zaštita industrijskog vlasništva - prava žiga u hrvatskom kaznenom pravu i praksi“, Hrvatski ljetopis za kazneno pravo i praksu (Zagreb), vol. 14, broj 2/2007. (969-998), str. 976.

${ }_{123}$ Kao sinonimi za industrijski dizajn često se rabe termini: industrijsko oblikovanje (obličje), model i uzorak, oblikovane tvorevine, industrijska estetika, inženjerski dizajn, mehanička umjetnost, tvornička umjetnost i dr. Usp. MANIGODIĆ, M., Industrijski dizajn - Zaštita modela i uzoraka u zemlji i inostranstvu, Pronalazaštvo, Beograd, 1988., str. 12.

124 Tako: JANEV, I., Svetska organizacija za intelektualnu svojinu, Beograd, 2009., str. 262.

125 Vidi stranicu: http://www.dziv.hr/hr/intelektualno-vlasnistvo/industrijski-dizajn/. 
Razlog posebne zaštite industrijskoga dizajna upravo je u ekonomskoj vrijednosti i privlačnosti lijepo opremljenih i vizualno privlačnih proizvoda. ${ }^{126}$ Naime, kada kupac bira robu, veoma često presudnu ulogu ima upravo vanjski izgled, odnosno oblik proizvoda, grafička oprema ambalaže, raspored crta i boja i sl., jer u masi podataka kupac često pamti samo navedene elemente. Takva ocjena i vrednovanje uspješnoga industrijskog oblikovanja izaziva u gospodarstvenika posve legitimnu želju da uloženim sredstvima i naporima izborene i stečene kreacije zadrže za sebe, za oblikovanje vlastitih proizvoda i u svoje poslovne svrhe, da bi mu kao snažno propagandno sredstvo što dulje pružale prednosti u gospodarskoj utakmici. Pravo je našlo način da ekonomsku kategoriju industrijskoga oblikovanja pretvori u pravnu kategoriju (industrijski dizajn) koja će na određeno vrijeme osigurati isključivo pravo korištenja. ${ }^{127}$

U nas je prihvaćeno anglosaksonsko viđenje industrijskoga dizajna kao jedinstvenoga intelektualnog vlasništva koje se štiti jednom prijavom, te on objedinjava raniju zakonsku podjelu na model i uzorak koja vrijedi za tradicionalnu francusku doktrinu na ovome području. ${ }^{128}$

126 Usp. JELISAVAC, S., Intelektualna svojina, Beograd, 2006., str. 81.

127 Tako: VERONA, A., Pravo industrijskoga vlasništva, Zagreb. 1978., str. 143.

128 Modelima i uzorcima kao vrstama industrijskoga dizajna štite se novi vanjski oblici tijela, slike i crteži industrijskih ili zanatskih proizvoda. Predmet zaštite i modelom i uzorkom vanjski je oblik, s time da je on kod modela trodimenzionalan, a kod uzorka dvodimenzionalan. Model i uzorak isključivo su estetske kreacije koje nemaju ni funkcionalne ni tehničke osobine. Kao apstraktne intelektualne kreacije mogu se bezbroj puta materijalizirati na industrijskim ili zanatskim proizvodima. Pravo na model i uzorak subjektivno je pravo koje pripada fizičkoj ili pravnoj osobi ako su ispunjeni materijalni i formalni uvjeti koje zakon predviđa. Više o tome u: VEDRINA, D., „Zaštita modela i uzorka u Republici Hrvatskoj“”, Hrvatski patentni glasnik,1994., 1, br. 2 - 3, str. 260; GROVES, P., Copyright and Designs Law, Graham and Trotman Ltd., s.1.,1991.; DAMSCHRODER, M. L., „Intellectual Property Rights and the GATT: United States Goals in the Uruguay Round“, Vanderbit Journal of Transnational Law, 21, (2-1988): 367; CORNISH, W. R., Intellectual Property: Patents, Copyright,Trade Marks, and Allied Rights, London, 1989. Uzorci su intelektualne kreacije (slike ili crteži) zaštićeni prema zakonu, kojima autori daju novo estetsko obilježje da bi se prema tomu obilježju mogao proizvesti industrijski ili zanatski proizvod. Uzorci (fr. dessins, njem. die Muster, engl. designs) intelektualne su kreacije kojima autori daju novo estetsko obilježje da bi se prema tomu obilježju mogao proizvesti industrijski ili zanatski proizvod. Uzorak je slika ili crtež koji mogu poslužiti za ugled i prenijeti se na industrijski i zanatski proizvod, a zaštićen je prema zakonu. BUKLJAŠ I., Pravo industrijskoga vlasništva, Zagreb, 1965., str. 110. Uzorak se može sastojati i od kombinacije slike i crteža. Riječ je, dakle, o dvodimenzionalnoj kreaciji, naslikanoj ili nacrtanoj (primjerice, nacrtani dezen prema kojemu će se proizvoditi tkanina). Modelom se štiti novi vanjski oblik određenoga industrijskog ili zanatskog proizvoda, odnosno njegova dijela. Model je tijelo koje predstavlja industrijski ili zanatski proizvod ili se na takav proizvod može primijeniti, a zaštićeno je prema zakonu (primjerice, novi tip kutije za krugoval). ROUBIER, P., Le droit de la propriete industrielle, Paris 1954., Tom II, str. 421. Uzorak je dvodimenzionalan, jer je riječ o slici ili crtežu na nekoj površini, dok je model kao tijelo trodimenzionalan. Ali izraz dvodimenzionalan ne treba shvatiti u strogo geometrijskome značenju, jer i slika ili crtež mogu biti reljefno izraženi (primjerice, šara na automobilskoj gumi). Vidi i: ČIZMIĆ, J., „Uzorak - zaštićeni znak razlikovanja u gospodarskome prometu“, Pravo u gospodarstvu, vol. 34, 1995., br. 9 - 10, str. 707-735; CEROVIĆ, V. D., „Kvaliteta i pouzdanost proizvoda u robnom prometu i međunarodnoj razmjeni - Posebni osvrt na pravo industrijske svojine“, Savremena administracija, Beograd, 1976., str. 44-49. Ne treba zaboraviti da se jedno vrijeme zaštita vanjskoga oblika proizvoda pružala i pravom koje se nazivalo industrijsko obličje, sukladno odredbama Zakona o industrijskome obličju Republike Hrvatske, Narodne novine, broj 78/99 i 127/99. 
2. Utjecaj je dizajna u svijetu sporta dalekosežan. Tamo gdje su uključeni slika i estetika, tu je i dizajn, a tamo gdje se pojavljuju novi materijali, uskoro slijedi estetika ili dizajn. ${ }^{129}$

\section{AUTORSKO PRAVO I SPORT}

1. Autorsko pravo jest pravo autora u pogledu svojega autorskog djela. Autorsko pravo isključivo je pravo autora na raspolaganje svojim književnim, znanstvenim ili umjetničkim djelima te djelima iz drugih područja stvaralaštva; srodna se prava slično odnose na prava umjetnika izvođača, proizvođača fonograma i emitiranja radija i televizije. ${ }^{130}$ Autorskim pravom uređuje se zaštita autorskih djela, odnosno intelektualnih tvorevina s područja književnosti, znanosti i umjetnosti. ${ }^{131}$

Razvitak je autorskoga prava znatno determiniran novim tehnologijama i njihovim svojstvima, koje se upotrebljavaju u svrhu nastanka autorskoga djela odnosno u svrhu njegove distribucije i korištenja. ${ }^{132}$ Međutim, uza sve napore, pravna regulativa uvijek zaostaje u odnosu na razvoj tehnologije, i tek što se urede pitanja vezana za refleksiju neke nove tehnologije na autorska prava, pojave se neka nova tehnološka rješenja, osobito ona vezana za digitalnu tehnologiju, koja traži odgovore i na pravnoj i legislativnoj razini, osobito na međunarodnopravnome planu.

2. Što se sporta tiče, autorskim pravom mogu biti zaštićene slike i prijenosi sa sportskih događaja, slike i lik sportaša, službene pjesme natjecanja, sportskih klubova i navijačkih skupina, sportske monografije, biografije, logo i znakovi klubova, promotivni materijali i sl. Autorsko pravo i srodna prava, posebice ona koja se odnose na radiodifuzijske organizacije, podupiru odnos između sporta i televizije i drugih medija. Televizijske i medijske organizacije plaćaju ogromne iznose novca za isključivo pravo na emitiranje sportskih događaja uživo. Primjerice, od ukupnih prihoda od 3,7 milijardi američkih dolara (bez prodaje ulaznica) koje je stvorio Svjetski kup FIFA 2010. u Južnoj Africi, dvije trećine ili 2,4 milijarde proizašle su iz prodaje prava emitiranja. Prodaja marketinških prava donijela je još

129 Vidi Sport and Intellectual Property, podatak na stranici: http://www.wipo.int/ip-sport/en/, posjet 16. III. 2018.

130 Podatak na stranici: http://www.dziv.hr/hr/intelektualno-vlasnistvo/o-intelektualnom-vlasnistvu/.

131 Vidi ALIJA, I., Pravo intelektualnoga vlasništva u Bosni i Hercegovini - zakoni u oblasti autorskoga $i$ srodnih prava $i$ kolektivno ostvarivanje autorskoga $i$ srodnih prava Bosne $i$ Hercegovine s objašnjenjima i registrom pojmova, Univerzitet u Travniku, Travnik, 2011., str. 104; VIGNJEVIĆ, L., Autorsko pravo i srodna prava u Bosni i Hercegovini, USAID \& Institut za intelektualno vlasništvo Bosne i Hercegovine, 2011., str. 8; GLIHA, I., Autorsko pravo - zbirka propisa s uvodnim tekstom, Informator, Zagreb, 2000., str. 1. Uvoda; BARTA, J. (red.), Prawo autorskie, System Prawa Prywatnego, Tom 13, C.H. Beck \& Institut nauk prawnych pan, Warszawa, 2003., str. 44; HARKE, D., Urheberrecht, Carl Heymanns Verlag, Köln - Berlin - Bonn - München, 1997., str. 9.

132 Tako u: VUKMIR, M., „Utjecaj razvoja tehnologija na autorsko pravo i pravna priroda predmeta zaštite intelektualnoga vlasništva“, Zbornik Hrvatskoga društva za autorsko pravo, Zagreb, 2001., vol. 2., str. 9. 
1,1 milijardu američkih dolara, a preostali dio pripada prodaji ugostiteljskih prava i licenciranja. ${ }^{133}$

Glazba dokazano vrlo povoljno utječe na poslovanje sportskih i rekreacijskih objekata. Glazba pripada autorima koji su je stvorili i ostalim nositeljima prava. Osim prava autora glazbenih djela, na glazbi postoje i prava umjetnika izvođača i prava proizvođača fonograma. Njihova prava također se ostvaruju kolektivno, a u Hrvatskoj ih predstavljaju udruge HUZIP (Hrvatska udruga za zaštitu izvođačkih prava) i ZAPRAF (Udruga za zaštitu, prikupljanje i raspodjelu naknada fonogramskih prava). Naknade za korištenje glazbenih djela u sportskim prostorima obračunavaju se kao mjesečni paušal. ${ }^{134}$

Sportski mediji (internetske stranice, TV-kanali i dr.) mogu sadržaj štititi autorskim pravom. Tako i sadržaj na internetskoj stranici Arena sport TV može biti zaštićen autorskim pravima. Sadržaj objavljen na internetskoj stranici Arena sport TV ne smije se reproducirati, distribuirati ili na bilo koji način koristiti u komercijalne svrhe bez izričitog pristanka Arena sport TV-a, ili koristiti na bilo koji način kojim se može prouzročiti šteta Arena sport TV-u ili bilo kojoj trećoj osobi u skladu s propisima. Dijelovi ili cijela internetska stranica ne mogu se kopirati, reproducirati, prenositi, objavljivati ili distribuirati bez prethodnog pisanog odobrenja Arena sport TV-a, osim u slučaju preuzimanja informacija i materijala i pohranjivanja na disk računala pojedinačnog korisnika radi osobne, neprofitabilne i nekomercijalne upotrebe. ${ }^{135}$

\section{SPORTSKA TAJNA ${ }^{136}$}

Sport je nedvojbeno djelatnost, odnosno područje u kojemu je određene podatke, radnje, poslove i postupke specifične za sport nužno zaštititi i štite se nekom od vrsta tajni ili stupnjeva tajnosti.

Naveli bismo samo neke od njih: metode treninga i priprema za utakmicu; pregovori o transferima i iznos transfera; podaci o bolesti i povredama igrača; plaće igrača i trenera; prava iz područja intelektualnog vlasništva; informacijski sustavi i baze podataka; sponzorski ugovori i drugi pravni poslovi; poslovni podaci, a posebno oni financijske naravi; osobni podaci u najširem smislu i sl.

Na žalost, svjedoci smo da se tajnom moraju štititi i neki nekada bizarni podaci poput vremena i mjesta odigravanja prijateljskih utakmica, vremena dolaska na

133 Vidi IP and Sports - Background Brief, podatak na stranici: http://www.wipo.int/pressroom/en/ briefs/ip_sports.html, posjet 16. III. 2018.

${ }_{134}$ Tako i više o tome na stranici: http://www.zamp.hr/korisnici/pregled/25/76/sportski-prostori, posjet 16. III. 2018.

135 Više o tome na stranici: http://www.tvarenasport.hr/pravila-koristenja, posjet 16. III. 2018.

136 Podloga za izradu ovoga rada bio je dijelom i tekst u knjizi ČIZMIĆ, J. - BOBAN, M. ZLATOVIĆ, D., Nove tehnologije, intelektualno vlasništvo i informacijska sigurnost, Sveučilište u Splitu, Pravni fakultet, Split, 2016., 786 str. 
utakmicu i mjesta boravišta, a sve zbog straha od navijačkih nereda ili drugih vrsta ometanja.

Sportsku tajnu dužni su čuvati razni sportski subjekti i sudionici u sportu: igrači, treneri, uprave klubova i tehničko osoblje, liječnici i drugi zdravstveni radnici, zastupnici i punomoćnici, financijska služba, poslovni partneri i dr.

Niz je razloga zbog kojih danas postoje brojne opasnosti i izazovi za očuvanje sportske tajne. Prije svega zbog toga što je u sami postupak zaštite uključen velik broj fizičkih i pravnih osoba, a pogotovo zbog toga što postoji stalni i veliki interes javnosti, navijača, hakera i medija za otkrivanjem podataka koji su zaštićeni nekim oblikom ili stupnjem tajnosti.

\section{ZAKLJUČAK}

Veliki značaj i utjecaj športa na svakodnevni život čine ga nedvojbeno sve većim društvenim, ali i ekonomskim fenomenom pa razvitak športa i pratećih djelatnosti prati niz novih pojava, izazova ali i prijetnji, što zahtijeva njegovo pomno praćenje i pravnu regulaciju. ${ }^{137}$

Već sredinom prošlog stoljeća krivotvorine i piratstvo postali su nadaleko raširen fenomen s globalnim utjecajem. Ovaj fenomen širi se s ekonomskim i političkim razvitkom koji se zbio u posljednja dva desetljeća, a karakterizira ga stalan rast međunarodne trgovine, internacionalizacija ekonomije, ekspanzija sredstava komunikacije te kolaps političkih sustava u središnjoj i istočnoj Europi i bivšem Sovjetskom Savezu, gdje su niknula nova, iznimno potentna tržišta za proizvodnju i konzumiranje krivotvorenih i piratskih roba. To se naslanja na razvoj informatičkog društva te na pojavu modernih, sofisticiranih tehnologija koje su prikladne za upotrebu u svrhu kopiranja roba. Pojava krivotvorina i piratstva proizvodi brojne štetne učinke ne samo na području poslovanja, nacionalnih ekonomija i zaštite potrošača, nego i na društvo u cijelosti, ${ }^{138}$ pa tako nije izuzeto ni područje sporta u najširem smislu riječi. Na tom planu trpe svi oblici intelektualnog vlasništva u sportu kao objekti povrede, a posebice žigovi kao najčešći pojavni i marketinški vidovi vlasnikove prezentacije na tržištu. ${ }^{139}$ 2009.

137 Vidi PRIMORAC, D., Uvodna riječ, u knjizi CRNIĆ, I. i dr., (Uvod u) Športsko pravo, Zagreb,

138 Detaljnije u Green Paper - Combating Counterfeiting and Piracy in the Single Market, Commission of the European Communities, Brussels, COM (98).

139 O tome i PRICA, „Povreda prava na žig“, Pravni život, broj 5/63., str. 32. i dr.; CORNISH, W. R., Intellectual Property, 3rd ed.,1996, Sweet \& Maxwell, MARETT, P., Intellectual Property Law, Sweet \& Maxwell, 1996., KERLY, Law of Trade Marks and Trade Names, 12th ed., 1986., with supplement 1994., Sweet \& Maxwell, VRANEŠEVIĆ, T., Upravljanje markama (Brand Management), Zagreb, 2007. 


\section{POPIS LITERATURE}

1. ALIJA, I., Pravo intelektualnoga vlasništva u Bosni i Hercegovini-zakoni u oblasti autorskoga $i$ srodnih prava i kolektivno ostvarivanje autorskoga i srodnih prava Bosne i Hercegovine s objašnjenjima i registrom pojmova, Univerzitet u Travniku, Travnik, 2011.

2. BAČIĆ, F. - PAVLOVIĆ, Š., Komentar Kaznenog zakona, Zagreb, 2004

3. BAGRA, S., „Korišćenje ljudskog obličja u komercijalne svrhe“, Uslužno pravo, Kragujevac, 2013. BALCARCZYK, J., „Sport image rights - a comparative overview“", Zbornik radova Pravnog fakulteta u Splitu, god. 47, 2010., broj 2.

4. BAMBAUER, D., „Legal responses to the challenges of sports patents“, Harvard Journal of Law \& Technology, Volume 18, Number 2, Spring 2005.

5. BADENHAUSEN, T., Full List: The World's 50 Most Valuable Sports Teams 2017, podatak na stranici: https://www.forbes.com/sites/kurtbadenhausen/2017/07/12/fulllist-the-worlds-50-most-valuable-sports-teams-2017/\#22a6bc774a05, posjet 16. III. 2018.

6. BARTA, J., (red.), Prawo autorskie, System Prawa Prywatnego, Tom 13, C.H. Beck \& Institut nauk prawnych pan, Warszawa, 2003.

7. BARTOLEC, G. B., ,Vatreni, Kauboji i Stara dama (metafora i metonimija u medijima)“, Hrvatski jezik, 2015., broj 1.

8. BARTOLUCI, S. - TOMIĆ, D., Više od riječi - neverbalna komunikacija trenera i sportaša (1. dio), str. 8-9. Podatak na stranici: http://ukth.hr/media/files/4-10bartoluci-2-2013.pdf. (22. XII. 2017.).

9. BEGIĆ, V., “Mate Parlov" postao “Doručak šampiona”, podatak na stranici: http://www.novilist.hr/novilist_public/layout/set/print/Kultura/Mate-Parlov-postaoDorucak-sampiona (22. XII. 2017.).

10. BOŽIĆ, I., 'Fudbalerke' i druge frizure nogometaša, podatak na stranici: https://www. srednja.hr/zabava/moda/fudbalerke-i-druge-frizure-nogometasa/ (22. XII. 2017.).

11. BUKLJAŠ, I., Privredno pravo s osnovama prava, Zagreb, 1978.

12. CAPAR, L., Ako danas želite biti originalni nemojte se tetovirati, Večernji list, 28. VIII. 2015., http://www.vecernji.hr/moda-i-ljepota/ako-danas-zelite-biti-originalninemojte-se-tetovirati-985324. (22. XII. 2017.).

13. CORNISH, W. R., Intellectual Property: Patents, Copyright,Trade Marks, and Allied Rights, London, 1989.

14. CRNIĆ, I., „Prava osobnosti i neimovinska šteta u športu“, u knjizi Uvod u športsko pravo, Zagreb, 2009.

15. ČIZMIĆ, J. - ZLATOVIĆ, D., Komentar Zakona o žigu, Zagreb, 2002.

16. ČIZMIĆ, J. - BOBAN, M. - ZLATOVIĆ, D., Nove tehnologije, intelektualno vlasništvo i informacijska sigurnost, Pravni fakultet Sveučilišta u Splitu, Split, 2016.

17. ČIZMIĆ, J., „Novost izuma“, Pravo u gospodarstvu, vol. 37, 1998., br. 4, str. 713726.

18. ČIZMIĆ, J., Ogledi iz prava industrijskog vlasništva, Split, 1998. 
19. ČIZMIĆ, J. - KAČER, H., „Pravna zaštita imidža sportaša u Republici Hrvatskoj“, u knjizi Hrvoje Kačer et al, Sportsko pravo, Sveučilište u Splitu, Pravni fakultet, Split, 2018., str. 379-423.

20. ČIZMIĆ, J., „Uzorak - zaštićeni znak razlikovanja u gospodarskome prometu“, Pravo u gospodarstvu, vol. 34,1995, br. 9 - 10, str. 707-735.

21. ČIZMIĆ, M., Je li tehnologija pojela sport?, Podatak na stranici: https://www.tportal. hr/tehno/clanak/je-li-tehnologija-pojela-sport-20130726. Posjet 18. II. 2019.

22. DANILOVIĆ, T., „Zaštita prava na žig“, Privredno pravni priručnik, god. XVI, 1978., br. 8 ,

23. DROPULIĆ, J., „Pravo na osobno ime“, Hrvatska javna uprava, god. 6., (2006.), br. 2, str. 121-138.

24. ĐURĐEVIĆ, N., Javne vlasti u sportu, Kragujevac, 2007.

25. FOLSOM, H. R. - GORDON, M. W. - SPANGOLE, J. A., Međunarodni trgovački poslovi - u sažetom obliku, Rijeka, 1998.

26. GAVELLA, N., Osobna prava, I. dio, Zagreb, 2000.

27. GLIHA, I., Autorsko pravo - zbirka propisa s uvodnim tekstom, Informator, Zagreb, 2000.

28. GROVES, P., Copyright and Designs Law, Graham and Trotman Ltd., s.l., 1991.

29. HARKE, D., Urheberrecht, Carl Heymanns Verlag, Köln - Berlin - Bonn - München, 1997.

30. HART/FAZZANI, Intellectual Property Law, sec. edit., Palgrave, Hampshire \& N.Y., 2000.

31. IVKOVIĆ, I., Top 10 nadimaka vrhunskih američkih sportaša, Podatak na stranici: http://www.tportal.hr/sport/magazin/138049/Top-10-nadimaka-vrhunskihamerickih-sportasa.html (22. XII. 2017.).

32. IVO PAVIĆ, Piercing - da ili ne, podatak na stranici: http://www.zupa-surkovac. com/hr/article/20/piercing-da_ili_ne (20. XII. 2017.).

33. JANEV, I., Svetska organizacija za intelektualnu svojinu, Beograd, 2009.

34. JELISAVAC, S., Intelektualna svojina, Beograd, 2006.

35. JEREMIAH, Merchandising Intellectual Property Rights, Wiley \& Sons, Inc., 1997.

36. KAČIĆ KARLIN, A., Kad sportaš loče, skandal je zajamčen!, Dnevno, 13. II. 2015., http://www.dnevno.hr/sport/kad-sportas-loce-skandal-je-zajamcen-144904. (22. XII. 2017.).

37. KENNY \& SAYWELL, Marketing and the Sydney 2000 Olympic Game, Intellectual Property Asia, No 12, 1999.

38. KERLY, Law of Trade Marks and Trade Names, 12th ed., 1986.

39. Kareem Abdul-Jabbar: Zašto sam prešao na islam, podatak na stranici: http:// balkans.aljazeera.net/vijesti/kareem-abdul-jabbar-zasto-sam-presao-na-islam. (22. XII. 2017.).

40. KOVAČIĆEK, T., Brend Nike je lansirao prvi sportski hidžab, podatak na stranici: https://www.gloria.hr/moda/novosti/brend-nike-je-lansirao-prvi-sportskihidzab/5733919/, posjet 16. III. 2018. 
41. LENKA GOSPODNETIĆ, „Sportaši i manekeni u tatoo salonima: muškarci biraju navijačke motive, žene simbole s porukom“, Slobodna Dalmacija, 24. VII. 2014., podatak na stranici: https://www.google.hr/?gfe_rd=cr\&ei=qP_fVY_yH4ve8gfuul7 YAg\#q=tetovaže+sportaši. (22. XII. 2017.).

42. LUKIĆ, J., Tetovaže u sportu: simbol, poruka, ili..., SK-SPORTKLUB, 3. I. 2014. http://www.sportklub.rs/tetovaze-u-sportu-simbol-poruka-ili., (22. XII. 2017.).

43. MANIGODIĆ, M., Industrijski dizajn - Zaštita modela i uzoraka u zemlji $i$ inostranstvu, Pronalazaštvo, Beograd, 1988.,

44. MANIGODIĆ, M., Zašstita izuma u YU, EZ i USA, Beograd, 1991.

45. MARETT, P., Intellectual Property Law, Sweet \& Maxwell, 1996.

46. MARJANOVIĆ, M., Strategije za izgradnju profesionalnog sportskog imidža, Savremenisport.com, 12. VII. 2014., http://savremenisport.com/teorija-sporta/ sportski-marketing/9/260/strategije-za-izgradnju-profesionalnog-sportskog-imidza.

47. MARUŠIĆ, S., Upravljanje markom na primjeru nogometnog kluba Manchester United, Diplomski rad, Split, 2012.

48. MATIĆ, S., Zbog Olimpijade se odrekao i imena, podatak na stranici: http://www. dw.com/hr/zbog-olimpijade-se-odrekao-i-imena/a-17429094 (22. XII. 2017.).

49. MIHOVILOVIĆ, M., „Veliki skandal najbogatijeg sportaša, Poslovni i sportski krah zbog seks afere“, Nacional br. 736, 2009-12-22, http://arhiva.nacional.hr/ clanak/74110/poslovni-i-sportski-krah-zbog-seks-afere (22. XII. 2017.).

50. OBRENOVIĆ, A., Novi imidž Lazara Markovića, Sportske.Net, 20. VII. 2015., http:// www.sportske.net/vest/dzet-set/novi-imidz-lazara-markovica-231575.html (22. XII. 2017.).

51. Od ideje do profita, Zagreb, 1998.

52. PARAĆ, Z., „Ciljevi patentne zaštite“, Privredno-pravna praksa, 1989., br. 2.

53. PARAĆ, Z., ,Kriteriji patentibilnosti po Zakonu o zaštiti izuma, tehničkih unapređenja i znakova razlikovanja“, Informator, br. 3007, str. 19-20.

54. PARAĆ, Z., „Opseg patentne zaštite“, Zbornik Pravnoga fakulteta u Zagrebu, 37, 1987., br. 2.

55. PAUN, V., To ti je neki sportski život: Čašica nam je svima u krvi, 24sata, 24. V. 2010., http://www.24sata.hr/sport/to-ti-je-neki-sportski-zivot-casica-nam-je-svimau-krvi-171444. (22. XII. 2017.).

56. PAVLIĆ, A., Imena luda stvaraju se svuda, http://www.hrsport.net/mobile/ blogovi/421911/vremeplov/imena-luda-stvaraju-se-svuda/ (22. XII. 2017.).

57. PERIĆ, J., „Zaštita pronalazaka“, Jugoslovensko pronalazaštvo, 1987., br. 306.

58. PODNAR, O., Tijelo kao reklamni pano, podatak na stranici: http://www.poslovni. hr/after5/tijelo-kao-reklamni-pano-129452\#. (22. XII. 2017.).

59. PRICA, ,Povreda prava na žig“, Pravni život, broj 5/63.

60. PRIMORAC, D., „Uvodna riječ“, u knjizi CRNIĆ, I. i dr. (Uvod u) Športsko pravo, Zagreb, 2009. 
61. QUEST, From Diana to Football - protection still found wanting (an update on personality character merchandising), Licensing executives society, New exchange, Issue 71: February - March 2000.

62. RADOLOVIĆ, A., „Prava ličnosti u građanskom pravu Hrvatske“, Vladavina prava, br. 1, Zagreb, 1998.

63. SOFTIĆ, L., Vizualni identitet $i$ brand/iranje, podatak na stranici http://savjetnik. ba/wp-content/uploads/2014/08/Vizualni-identitet-i-brandiranje.pdf (22. XII. 2017.).

64. BARTOLUCI, S. - TOMIĆ, D., Više od riječi - neverbalna komunikacija trenera $i$ sportaša (1. dio), str. 8-9., http://ukth.hr/media/files/4-10-bartoluci-2-2013.pdf. (22. XII. 2017.).

65. ŠLJIVAK, M., Srbijanska sportiskinja je jedinstvena u svijetu sporta, 6. X. 2014., Pročitaj više na: http://sportsport.ba/magazin/srbijanska-sportiskinja-je-jedinstvenau-svijetu-sporta/142249. (22. XII. 2017.).

66. ŠUPERINA, M. - KOLAR-GREGORIĆ, T. - CVITANOVIĆ, L., „Zaštita industrijskog vlasništva - prava žiga u hrvatskom kaznenom pravu i praksi“, Hrvatski ljetopis za kazneno pravo i praksu (Zagreb), vol. 14, broj 2/2007 (969-998).

67. VEDRINA, D., „Zaštita modela i uzorka u Republici Hrvatskoj“, Hrvatski patentni glasnik,1994., 1, br. 2 - 3.

68. VERONA, A., Pravo industrijskoga vlasništva, Zagreb, 1978.

69. VIGNJEVIĆ, L., Autorsko pravo i srodna prava u Bosni i Hercegovini, USAID \& Institut za intelektualno vlasništvo Bosne i Hercegovine, 2011.

70. VRANEŠIĆ, V., Povratak najgore frizure svih vremena: Fudbalerka uzvraća udarac, podatak na stranici: http://net.hr/zena/moda/povratak-najgore-frizure-svih-vremenafudbalerka-uzvraca-udarac/ (22. XII. 2017.).

71. VRANEŠEVIĆ, T., Upravljanje markama (Brand Management), Zagreb, 2007.

72. VUKMIR, M., „Utjecaj razvoja tehnologija na autorsko pravo i pravna priroda predmeta zaštite intelektualnoga vlasništva“, Zbornik Hrvatskoga društva za autorsko pravo, Zagreb, 2001., vol. 2.

73. ZLATOVIĆ, D., Žigovno pravo, Vizura, Zagreb, 2008.

74. Znate li zašto je Cassius Clay postao Muhammad Ali?, http://www.slobodnadalmacija. hr/sport/ostalo/clanak/id/314636/znate-li-zasto-je-cassius-clay-postao-muhammadali (22. XII. 2017.). 


\section{PROTECTION OF SPORTS TO RELATED INTELLECTUAL PROPERTY RIGHTS}

Relations in sport cannot be imagined beyond the legal framework defined by sports law. Sport and legal regulation are reflected in a deep connection, because the most important and basic element of sport is its legal regulation and legal protection.

The author presented the legal regulation and protection of the rights of various subjects in sport to intellectual property rights.

Key words: sport, intellectual property 